\title{
Conflicts of Interest in Sell-side Research and The Moderating Role of Institutional Investors * +
}

\author{
Alexander Ljungqvist \\ Stern School of Business \\ New York University \\ and $C E P R$ \\ Laura T. Starks \\ McCombs School of Business \\ University of Texas, Austin
}

\author{
Felicia Marston \\ McIntire School of Commerce \\ University of Virginia
}

\author{
Kelsey D. Wei \\ School of Management \\ Binghamton University
}

\author{
Hong Yan \\ McCombs School of Business \\ University of Texas, Austin
}

January 18, 2005

\footnotetext{
* Thanks for helpful comments and suggestions go to Werner Antweiler, Daniel Bradley, Martin Gruber, S.P. Kothari (our discussant), and seminar participants at Yale University, HEC Paris, the University of Virginia, and the "Conference on Agency Problems and Conflicts of Interest in Financial Intermediaries" sponsored by the Federal Reserve Bank of New York, the Dice Center for Research in Financial Economics of the Ohio State University, and the Journal of Financial Economics. We gratefully acknowledge the contribution of Thomson Financial for providing broker recommendations data, available through the Institutional Brokers Estimate System. These data have been provided as part of a broad academic program to encourage earnings expectations research. All errors are our own.

${ }^{\dagger}$ Address for correspondence: Salomon Center, Stern School of Business, New York University, Suite 9-160, 44 West Fourth Street, New York NY 10012-1126. Phone 212-998-0304. Fax 212-995-4220. e-mail aljungqv@stern.nyu.edu.
} 


\title{
Conflicts of Interest in Sell-side Research and The Moderating Role of Institutional Investors
}

\begin{abstract}
Because sell-side analysts are dependent on institutional investors for performance ratings and trading commissions, we argue that analysts are less likely to succumb to investment banking or brokerage pressure in stocks highly visible to institutional investors. Examining a comprehensive sample of analyst recommendations over the 1994-2000 period, we find that analysts' recommendations relative to consensus are positively associated with investment banking relationships and brokerage pressure, but negatively associated with the presence of institutional investor owners. The presence of institutional investors is also associated with more accurate earnings forecasts and more timely re-ratings following severe share price falls.
\end{abstract}

Key words: Analyst recommendations, Analyst forecast accuracy, Investment banking, Conflicts of Interest, Institutional investors, Banking Relationships.

JEL classification: G20, G21, G23, G24 


\section{Introduction}

Recent events highlight potential conflicts of interest in the production of investment research stemming from the competing roles sell-side analysts play in financial markets. In this paper we examine whether the presence of institutional investors moderates these conflicts of interest. We argue that the cost to publishing biased and misleading research should be larger in stocks that are highly visible to institutional investors, for two reasons. First, institutional investors cast votes for the "best" analysts in each sector in the annual Institutional Investor "all-star" poll. A high ranking directly influences the analyst's remuneration and career prospects and so provides an incentive to produce useful and timely research. Second, while most institutions do not pay directly for sell-side research, they pay for it implicitly by way of their trading commissions. In fact, institutional investors commonly poll their portfolio managers to decide how to allocate their trading commissions among brokerage firms. Allocations tend to be based, at least in part, on which sell-side analysts provide more value-added research. Thus, assuming institutions value useful and unbiased research, they have the means to encourage its production. In support of this assumption, Frankel, Kothari, and Weber (2004) argue that institutional ownership in a stock increases the demand for informative analyst research.

A sell-side analyst's primary role is to act as an informational intermediary, channeling information - in the form of investment recommendations, earnings forecasts, and detailed reports - from companies to investors. However, investors are not the analyst's only constituency. Companies care about what the analyst has to say about their stocks, and may take their investment banking business elsewhere if they are unhappy with the analyst's opinion. Thus, sell-side analysts who work for integrated investment banking houses rather than research boutiques may come under implicit (or occasionally explicit) pressure to publish more favorable research about their employers' current or potential relationship clients to help boost investment banking fee revenue (e.g., Michaely and Womack, 1999; Dugar and Nathan, 1995; Lin and McNichols, 1998). Kolasinski and Kothari (2004) 
term this the "bribery" hypothesis. ${ }^{1}$

Similarly, analysts may come under pressure to help generate brokerage commissions. Irvine (2003), Jackson (2003), Agrawal and Chen (2004), and Cowen, Groysberg, and Healy (2003) argue that bullish research stimulates trading (in the face of short-sale constraints), generating additional brokerage revenue. This "brokerage pressure" also provides incentives for analysts to present positively biased opinions.

Finally, Francis and Philbrick (1993), Das, Levine, and Sivaramakrishnan (1998), and Lim (2001) argue that analysts positively bias their forecasts and recommendations in order to stay on friendly terms with firm management. Insufficiently flattering research may result in a company refusing to provide the analyst with timely information or access to senior management, undermining the analyst's ability to be an effective informational intermediary.

Our findings corroborate previous evidence suggesting that analysts are subject to investment banking and brokerage pressure: Analysts issue more optimistic recommendations when they are affiliated with investment banks that have an existing relationship with the firm covered, and when they work for banks with larger brokerage businesses. ${ }^{2}$ But importantly, our findings also support the hypothesis that the presence of institutional investors provides incentives for analysts to publish unbiased or less biased research.

Our analysis of the role of institutional investors provides an economic foundation for prior findings that analyst behavior appears to be guided by career concerns. Analysts who build reputations for providing reliable, accurate, unbiased, and timely forecasts and recommendations generate

\footnotetext{
${ }^{1}$ Other studies have examined whether institutional investors, or investors in general, react differently to affiliated versus unaffiliated analyst forecasts and whether the profitability of trading on the recommendations of the two groups differs. See, for example, Iskoz (2003); Malmendier and Shanthikumar (2004); Bradley, Jordan, and Ritter (2004); Chen (2004); and Barber, Lehavy, and Trueman (2004).

${ }^{2}$ This apparently greater optimism among affiliated analysts may be due to investment banking pressure, or it could result from companies purposely hiring investment banks whose analysts view their prospects more optimistically (Kothari, 2000). Ljungqvist, Marston, and Wilhelm (2004) provide evidence against this alternative "selection" hypothesis, by showing that favorably biased recommendations do not increase a bank's chances of being selected to manage the company's future financing activities. Clarke et al. (2004a) come to a similar conclusion in their analysis of the determinants of investment bank market share changes, and Kolasinski and Kothari (2004) rule out the idea that "CFOs bribe investment banks with underwriting business in return for favorable analyst coverage."
} 
additional trading business for their brokerage firms (Irvine, 2003; Cowen, Groysberg, and Healy, 2003; Jackson, 2003) and are more likely to be hired by the most prestigious investment banks (Hong and Kubik, 2003; Hong, Kubik, and Solomon, 2000). Poorly performing analysts, on the other hand, generate less brokerage business and are ultimately associated with higher job turnover (Mikhail, Walther, and Willis, 1999). Most analysts' reputational capital and hence career prospects ultimately depend on institutional investors' views of the quality of their research. Institutional investors periodically evaluate an analyst's performance relative to other analysts, both directly (e.g., in the annual Institutional Investor poll) and through their choice of which brokerage firms to use. Thus, we view institutional investors as the ultimate arbiters of an analyst's reputation.

In sum, we argue that analysts face a trade-off between generating revenues for their employers' brokerage and investment banking businesses and their private career concerns. While investment banking and brokerage pressure each may cause analysts to provide optimistic opinions, biasing their research undermines their reputation with institutional investors who can express their dissatisfaction with tainted analyst research in a variety of ways. As a result, analysts are less likely to give in to investment banking or brokerage pressure in stocks that are highly visible to their institutional investor constituency. Empirically, we expect less conflicted behavior in stocks that are primarily owned by institutional (rather than individual) investors. This is the central hypothesis we test.

We investigate three dimensions of analyst behavior. Our first set of tests focuses on the investment recommendations analysts periodically issue on companies. We use a comprehensive sample of 6,337 non-financial companies over the 1994-2000 period for which analyst recommendations are available in the $\mathrm{I} / \mathrm{B} / \mathrm{E} / \mathrm{S}$ database and institutional investor holdings are available in the CDA Spectrum database. Controlling for a number of analyst and firm characteristics, we find that analysts issue more aggressive recommendations (relative to the consensus recommendation at the time) the greater the presumed pressure from the investment banking and brokerage operations of the analyst's employer. This optimism is offset by two countervailing influences. First, as conjectured, the 
presence of institutional investors appears to moderate investment banking pressure. We find that a given analyst issues more cautious recommendations for those of her stocks that are predominantly owned by institutional investors, all else equal. This negative relation between analysts' recommendations and institutional ownership appears stronger when there are more institutions holding larger blocks, and for firms whose institutional holdings are concentrated in the hands of the largest institutional investors. The results appear robust to controlling for endogenous coverage decisions. Second, the investment bank's reputational capital is important. Consistent with Ljungqvist, Marston, and Wilhelm (2004), we find that analysts employed at banks that have large equity underwriting market share and whose underwriting clients are more "loyal" issue significantly less aggressive recommendations, suggesting that analysts employed by such banks face less employer pressure to inflate their recommendations.

Our second set of tests focuses on earnings forecast accuracy, that is, the absolute forecast error relative to subsequently realized earnings. While we find no evidence that analysts jeopardize their forecast accuracy when bowing to investment banking or brokerage pressure to inflate recommendations, we show that analysts strive for greater accuracy in those stocks that are predominantly held by institutional investors.

Our third set of tests examines a different way in which analyst behavior could be conflicted. Lin, McNichols, and O'Brien (2003) examine differences in the speed with which affiliated versus unaffiliated analysts respond to negative information about a company, finding that affiliated analysts downgrade their recommendations more slowly. We show that analysts react more quickly to bad news - usually by downgrading the stock - the greater is institutional ownership, though unlike Lin, McNichols, and O'Brien we find little evidence that strong client relationships prompt analysts to delay lowering their recommendations following bad news.

We focus on the 1990s because the repeal of the Glass-Steagall Act and the consequent increase in competition in the securities underwriting business likely increased investment banking pressure 
during that period. Ljungqvist, Marston, and Wilhelm (2004) argue that in the mid to late 1990s, entry by commercial banks into the underwriting market combined with enormous underwriting deal flow upset an equilibrium in which analyst reputational concerns moderated the conflict of interest between investment banking and research. In addition, Michaely and Womack (1999) point out that changes in the strategies of investment banks resulted in closer ties between sell-side analysts and their employers' investment banking operations, exacerbating the potential conflicts of interest analysts faced. However, the rapid increase in the demand for capital during the 1990s was accompanied by rapid growth in the pension fund and mutual fund markets. Thus, institutional investors gained power and according to our hypothesis should have moderated the sell-side analyst's conflicts of interest.

Our paper differs from earlier studies in both scope and focus. Many earlier studies of investment banking conflicts restrict their samples to recent issuers of equity or debt securities. By contrast, we examine analyst opinions on all companies for which data are available, while controlling for their issuance history. This approach allows us to make more general statements regarding analyst conflicts of interest. Several concurrent studies also study analysts' opinions in this more general way (e.g., Agrawal and Chen, 2004; Clarke et al., 2004a, 2004b; Cowen, Groysberg, and Healey, 2003; Jacob, Rock, and Weber, 2003), but they do not examine how the presence of institutional investors in stocks covered by the analysts affects analyst behavior. Thus, our understanding of the effects of the competing incentives on the quality of analysts' opinions has been incomplete. In addition, although some concurrent studies examine the incentive effects of analyst reputation and brokerage commissions, our approach is more direct in that it examines the primary source of these incentives, the presence of institutional investors. Further, because analysts' earnings forecasts are potentially subject to both an optimism and pessimism bias throughout the year (e.g., O'Brien, 1988; Matsumoto, 2002; Richardson, Teoh, and Wysocki, 2004), our approach of focusing on recommendations has the additional advantage that recommendations are not subject to a pessimism bias.

We describe the economic structure of our empirical model and our estimation approach in the next 
section. Section 3 describes our data and our proxies for the characteristics of analysts, banks, and companies as well as the bank-company relationships. Our three sets of empirical tests are reported in Sections 4 through 6. We provide concluding comments in Section 7.

\section{The Empirical Model}

\subsection{Economic Structure of the Model}

In this section, we outline the economic structure of our models of analyst recommendations and forecast accuracy and provide an overview of the key variables. We defer precise specification of the variables to Section 3. The model of analyst reaction times to bad news will be outlined in Section 6.

Our first set of tests focuses on the effect of institutional equity holdings on the relative recommendation issued by analyst $i$ at bank $j$ for company $k$ at time $t$. By relative recommendation we mean the investment recommendation (strong buy, buy, hold, underperform, or sell) featured on the cover of the analyst's stock report, adjusted for the consensus recommendation to ensure comparability across stocks. While many early studies of potential analyst conflicts examine optimism in earnings forecasts, examining optimism in recommendations instead provides an important advantage. Company managers purportedly prefer positive earnings surprises, providing incentives to analysts to lowball their earnings forecasts so that the company can beat their forecasts (e.g., O’Brien, 1988). Thus, earnings forecasts have competing optimistic and pessimistic influences. In contrast, there is no obvious incentive to provide a pessimistic recommendation.

Analysts' recommendations provide a good proxy for the value and bias in an analyst's report. Surveys by Institutional Investor (see, e.g., the October 2004 cover story) show that what institutions value most are the analyst's integrity and professionalism, her accessibility and responsiveness, and her industry knowledge. These traits are not easily measurable, but an analyst's recommendations and recommendation changes contain aspects of these traits. Further, the narrative that accompanies Institutional Investor's profiles of the top analysts in each industry group stresses institutional investors' views of the analysts' recommendations, including both upgrades and downgrades. 
Recent academic research suggests that investment bankers at times pressure their analyst colleagues to provide more favorable recommendations for companies that are, or may become, investment banking clients (e.g., Michaely and Womack, 1999). This calls for controls for pre-existing underwriting relationships between the company and the bank employing the analyst, and (to capture potential future clients) for measures of the company's fee-generating capacity. Similarly, analysts may come under pressure to publish positive research to make it easier for the bank's sales force to generate brokerage commissions (e.g., Irvine, 2003). Conceptually, it is useful to think of investment banking and brokerage pressure as taking the form of promises of large year-end bonuses (though unlike relationships and measures of fee-generating capacity, these are not directly observable).

Research is an experience good so analysts have incentives to build and protect their reputations for providing meaningful recommendations. Thus, self-interested analysts should weigh career concerns against any immediate expected payoffs from cooperation with investment bankers and brokers. This is particularly true if the company in question is largely owned by institutions. As pointed out earlier, institutional investors evaluate analysts periodically through votes and surveys and thus indirectly influence analysts' bonuses and career prospects. Therefore, the presence of institutional investors in stocks covered by analysts can potentially counteract the pressure to inflate recommendations. Highly regarded analysts have particularly much to lose, and so should be more conservative in their recommendation behavior. In the same spirit, Ljungqvist, Marston, and Wilhelm (2004) find that highly reputable banks are less likely to risk their reputation capital by inducing their analysts to publish biased research. Thus, bank reputation should also reduce underwriting pressure.

The resulting model can be written as follows:

$$
A_{i, k, t}=\alpha C_{k, t}+\beta I_{i, t}+\theta R_{i, k, t}^{j}+\gamma B_{i, t}^{j}+\varepsilon_{i, k, t}
$$

where

- $A_{i, k, t}$ is analyst $i$ 's recommendation (relative to consensus) for company $k$ at time $t$;

- $C_{k, t}$ is a vector of company characteristics, including institutional equity holdings and measures of 
the company's capability of generating future investment banking fee revenue;

- $I_{i, t}$ is a vector of analyst characteristics proxying in part for reputation-related career concerns;

- $R_{i, k, t}^{j}$ is a vector describing company $k$ 's prior relationships with the bank employing analyst $i$ (note that for a given company $k, R_{i, k, t}^{j}$ varies across time $t$ and across analysts $i$, as long as they work for different banks $j$, but is constant for a given analyst in a given quarter; in other words, it has no separate variation across banks $j$ and so is not subscripted $j$ ); and

- $B_{i, t}^{j}$ is a vector of bank characteristics, which include proxies for the bank's reputation capital and the extent of brokerage pressure ( $B_{i, t}^{j}$ varies across $t$ and $i$ but has no separate variation across $j$ ). Equation (1) suggests a panel set-up, though note this panel has variation in three dimensions: $i, k$, and $t$. The unit of observation is an analyst $i$ (working for bank $j$ ) making a recommendation for company $k$ in quarter $t$. Some explanatory variables vary only across companies $k$ and time $t$. Others vary only across analysts $i$ and time $t$. The remainder vary across both $k$ and $i$, as well as $t$. This structure affects our interpretation of the results. Consider a given stock $k$ that is covered at time $t$ by several analysts $i . k$ 's institutional ownership (contained in $C_{k, t}$ ) does not vary across the analysts, yet the trade-off between career concerns and investment banking and brokerage considerations will differ across analysts $i$, in line with each analyst's reputation (in $I_{i, t}$ ), her bank's reputation and brokerage needs (in $B_{i, t}^{j}$ ), and the strength of the relationship between company $k$ and the analyst's bank. Thus, we expect different analysts to behave differently towards the same company.

Alternatively, consider a given analyst $i$ who at time $t$ covers several stocks $k$. The analyst's reputation and her bank's reputation do not vary across the stocks, yet the trade-off between career concerns and investment banking considerations will differ across stocks $k$, in line with each stock's institutional ownership and the strength of the relationship between company $k$ and the analyst's bank. Thus, we expect a given analyst to behave differently across the companies she covers, with more aggressive recommendations for relationship clients and less aggressive recommendations for 
companies that are highly visible to the institutional investor community.

Our second set of tests focuses on earnings forecast accuracy. These models are specified as in equation (1), except with a measure of forecast accuracy rather than relative recommendations as the dependent variable. We expect analysts to strive for greater accuracy in stocks that are predominantly held by institutional investors. The effect of prior underwriting relationships is ambiguous. On the one hand, analysts might help investment banking clients by low-balling their earnings forecasts to generate positive earnings surprises. On the other, analysts might be privy to superior or even inside information obtained through their banks' underwriting or general banking relationships.

\subsection{Econometric Structure of the Model}

A natural way to decompose the error $\varepsilon_{i, k, t}$ in equation (1) is as follows:

$$
\varepsilon_{i, k, t}=\eta_{i}+v_{k}+v_{t}+u_{i, k, t}
$$

where $\eta_{i}, v_{k}, v_{t}$, and $u_{i, k, t}$ are assumed to be i.i.d. and mutually independent with mean zero and variances $\sigma_{\eta}^{2}, \sigma_{v}^{2}, \sigma_{v}^{2}$, and $\sigma_{u}^{2}$, respectively. The first three error terms can be interpreted as omitted variables that vary unidimensionally across analysts, firms, and time, respectively. These are the threedimensional analogues of the familiar "firm" and "time" effects in standard two-way panel models.

\subsection{Estimation}

Equations (1) and (2) define a three-way panel model. Some three-way estimators have been derived in the spatial econometrics literature. Specifically, Antweiler (2001) derives a random effects estimator for unbalanced panel data for the special case where the random effects are nested. That is, $i$ is a sub-group of $k$ (which may be a sub-group of $l$, and so on), and one has a time series on each (not necessarily of equal length). In his example, one might have time series observations from multiple points inside a city, there are multiple cities within each state, and there are city and state random effects. Our model differs from this hierarchical structure in that our panel dimensions are not nested: The same analyst $i$ covers multiple stocks $k$, so our panel is one with "overlapping" random effects. Customized estimators for such panels do not currently exist. 
Therefore, we follow the literature and estimate equations (1) and (2) focusing on one of the two random effects, $v_{k}$ or $\eta_{i}$, at a time. Specifically, we first include analyst effects to remove unobserved heterogeneity across analysts $\eta_{i}$ while ignoring unobserved heterogeneity across stocks $v_{k}$.

Alternatively, we include company effects to remove unobserved heterogeneity across stocks $v_{k}$ while ignoring unobserved heterogeneity across analysts $\eta_{i}$. In either case, the resulting coefficient estimates are consistent as long as the remaining error term is independent of the regressors (though in general they are inefficient). A comparison of the coefficient estimates yields insight into the extent of any remaining bias. In addition to these random-effects specifications (estimated using GLS), we estimate Fama-MacBeth (1973) regressions of equation (1) as an additional robustness check.

Note that we estimate equation (1) in calendar time using the universe of listed companies for which data are available. Ljungqvist, Marston, and Wilhelm (2004) estimate a recommendations model similar to ours but in event time, for a sample of companies engaged in capital market transactions and ignoring the role of institutional investors in mitigating analyst conflicts of interest.

\subsection{Endogenous Coverage Selection}

A possible complication may arise if analysts are strategic in choosing which companies to cover (McNichols and O'Brien, 1997). One of the key determinants of the coverage decision may be institutional ownership (e.g., O’Brien and Bhushan, 1990): Since institutional investors determine the rankings analysts receive in the annual Institutional Investor magazine survey, which in turn influence bonuses and career prospects, analysts may devote more of their scarce research time to stocks with higher institutional ownership. Econometrically, this means that we observe $A_{i, k, t}$ only if analyst $i$ decides it is worth her while to cover stock $k$.

Estimating selection models in the presence of random effects is computationally extremely intensive, for two reasons: (1) The highly nonlinear likelihood function; and (2) the large size of our dataset once we consider all cases where any given bank $j$ could have provided research coverage for any given company $k$. Instead, in Section 4.2 we explore the robustness of our results to modeling 
selection without including random effects (i.e., Heckman (1979)). We also show that our results continue to hold for the very largest companies. Arguably, analysts have less discretion with respect to covering the largest companies, so selection is less likely to play a role.

\section{Data}

\subsection{The Sample}

Our dataset consists of the intersection of two large databases: The CDA Spectrum/Thomson Financial database, constructed from institutional investors' $13 \mathrm{f}$ filings, and the $\mathrm{I} / \mathrm{B} / \mathrm{E} / \mathrm{S}$ database of research analyst recommendations. Quarterly $13 \mathrm{f}$ filings are available since the $1980 \mathrm{~s}$, but we focus on the period 1994-2000 for two reasons: I/B/E/S began tracking analyst recommendations in late 1993, and the late 1990s is the period during which analyst conflicts of interest are expected to have been most severe (Michaely and Womack, 1999; Ljungqvist, Marston, and Wilhelm, 2004).

Institutions with more than $\$ 100$ million in equities must report their equity ownership in quarterly $13 f$ filings to the SEC. The majority of institutions (such as pension funds, insurance companies, bank trust departments, endowments, foundations, and mutual funds) are required to report equity positions of greater than 10,000 shares or $\$ 200,000$ in market value for all firms traded on an exchange or quoted on the Nasdaq National Market System. Non-reporting institutions include specialist firms, some public pension funds, most hedge funds, and smaller money managers. The institutions report aggregate holdings for their firm (say, a mutual fund family), regardless of how many individual fund portfolios they have. This aggregation within an institution helps us because institutions typically determine brokerage commission allocations on an aggregate basis across their portfolio managers.

Between 1994 and $2000 \mathrm{I} / \mathrm{B} / \mathrm{E} / \mathrm{S}$ records 181,942 recommendations for 9,227 non-financial companies by 6,287 analysts at 479 brokerages and investment banks. Not every company in the Spectrum database is covered by I/B/E/S and vice versa. Between 1994 and 2000, Spectrum covers 11,306 unique companies (based on six-digit CUSIPs), while I/B/E/S includes recommendations for 7,303 unique companies once we focus on the largest investment banks (see Section 3.2). The 
intersection of the two datasets contains 6,337 unique companies. ${ }^{3,4}$

Companies spend between one and 28 quarters in our dataset, with an average and median of 17 quarters. In a given quarter, the average company is covered by 5.6 analysts at the major investment banks. The total number of firm-analyst quarters in the recommendations dataset is 230,268 , after excluding 5,264 cases where an analyst makes recommendations anonymously. ${ }^{5}$

Table 1 describes the sample. In the average (median) company, institutions collectively hold $52.8 \%(55.5 \%)$ of the outstanding equity. Average (median) fiscal year-end equity market capitalization is $\$ 6,645$ million ( $\$ 1,218$ million). To assess how actively our sample companies access the capital markets, we cumulate the amount of equity or debt they have raised during the five years preceding a given quarter $t$. Around $57 \%$ of companies raise equity (averaging a cumulative $\$ 320.7$ million) while around 45\% raise debt (averaging $\$ 936.5$ million). Active issuers may attract more favorable recommendations, if past capital raising is indicative of their future fee-generating capacity (and if analysts respond to investment banking pressure).

\subsection{Sample Underwriters}

To keep the dataset to a manageable size, we follow Ljungqvist, Marston, and Wilhelm (2004) in focusing attention on the 16 largest investment banks judged by debt and equity underwriting market share in 2000-2002. Collectively, these banks account for at least $90 \%$ of the debt and equity underwriting markets by value over the sample period. They employ 3,313 of the 6,287 analysts and account for more than half the recommendations covered in I/B/E/S between 1994 and 2000. In decreasing order of market share, the 16 banks are Goldman Sachs, Merrill Lynch, Citibank Smith

\footnotetext{
${ }^{3}$ It is possible that the 966 companies that are in $\mathrm{I} / \mathrm{B} / \mathrm{E} / \mathrm{S}$ but not in Spectrum are exclusively held by individual shareholders. If so, we could set institutional holdings equal to zero and retain the 966 companies. It is equally possible that these companies are randomly missing from Spectrum despite having institutional shareholders. This is what we assume, though our results are qualitatively unchanged if we treat them as $100 \%$ individually-owned instead.

${ }^{4}$ Of the 4,969 firms that are in Spectrum but not in our I/B/E/S data, 2,120 can be found in the I/B/E/S recommendations file if all (rather than just the largest) banks are considered. The remaining 2,849 firms may be missing because they attracted no analyst coverage during the sample period, because of gaps in $\mathrm{I} / \mathrm{B} / \mathrm{E} / \mathrm{S}$ 's data collection, or due to inconsistent CUSIPs between I/B/E/S and Spectrum.

5 These are excluded because we require the analyst's identity to be able to measure her characteristics.
} 
Barney, CS First Boston, Morgan Stanley, JP Morgan Chase, Lehman Brothers, Banc of America, UBS Warburg, Deutsche Bank, Bear Stearns, Prudential Volpe, CIBC World Markets, Fleet Boston (Robertson Stephens), SG Cowen Securities, and Thomas Weisel Partners.

Many of the sample banks are the product of mergers (or demergers) and acquisitions during the sample period, so we also include their predecessors. For example, JP Morgan Chase is the result of mergers involving JP Morgan, Chase, Chemical Bank, Hambrecht \& Quist, and Manufacturers Hanover, among others. All of these are included in the dataset (insofar as they employed analysts issuing recommendations for firms covered in Spectrum).

\subsection{Bank Characteristics}

We use prior-year equity underwriting market share to proxy for a bank's reputation capital, following Megginson and Weiss (1991). The underlying underwriting data are obtained from Thomson Financial's SDC U.S. New Issues database. Before computing market shares, we exclude all equity transactions by firms classified as SIC 6000-6999 (financial institutions, etc.) and SIC 9000-9999 (government agencies, etc.). In the case of two or more joint lead underwriters, each bank is given equal credit for a transaction. A bank's market share then is the amount of equity it raised for its clients in the prior calendar year (ignoring overallotment options) divided by the total amount of equity raised by all issuers that year. Following a merger between two banks, the surviving entity is credited with both banks' deals. As Table 1 shows, the average company is covered by an analyst employed at a bank with a $5.2 \%$ equity underwriting market share.

Our second bank characteristic is a "loyalty index" borrowed from Ljungqvist, Marston, and Wilhelm (2004) which measures how often a bank retains its clients in consecutive deals. ${ }^{6}$ The average bank in our sample retains $62.2 \%$ of its clients, with a range between zero and $100 \%$.

\footnotetext{
${ }^{6}$ Define $J_{c, k}=1$ if bank $j$ acted as lead underwriter in company $k$ 's penultimate equity deal in the five years to quarter $t$, and 0 otherwise. Define $J_{r, k}=1$ if bank $j$ lead-managed company $k$ 's most recent equity deal in the same window, and zero otherwise. Then the loyalty index for bank $j$ in quarter $t$ equals $\Sigma_{k} J_{c, k} J_{r, k} / \Sigma_{k} J_{c, k}$, that is, the number of retained clients over the total number of clients.
} 


\subsection{Brokerage Pressure}

It is presumably hard to interest brokerage clients in buying stocks that the bank's analyst has expressed a negative opinion about. The resulting pressure to publish positive research to stimulate brokerage business should be greater at banks with larger brokerage businesses. Absent data on brokerage revenue, we proxy for the size of the brokerage business using the annual number of registered representatives listed in the Securities Industry Yearbook. ${ }^{7}$ This variable ranges from 20 to 19,000 brokerage employees, with an average of 3,798 and a median of 948. Many banks do not list retail and institutional brokers separately, so we use the total number of registered representatives. However, the brokerages with the largest number of registered representatives are clearly those catering extensively to retail clients.

\subsection{Investment-Banking Pressure}

We proxy for investment banking pressure with the strength of a company's relationship with a particular bank. ${ }^{8}$ This is estimated as the bank's share of the company's previous underwriting mandates, coded as follows. For company $k$ in quarter $t$, we determine whether it extended an underwriting mandate to bank $j$ or any of $j$ 's predecessors (but not $j$ 's successors). If so, we accumulate the proceeds from the deals that bank $j$ and its predecessors managed for company $k$ in the preceding five years, ${ }^{9}$ and divide by the total raised by the company to reduce the impact of differences in scale across firms. This measure ranges from zero (no relationship) to one (when the company maintained an exclusive banking relationship). It is computed separately for debt and equity deals, and for any bankcompany pair in the sample. The underlying underwriting data are obtained from Thomson Financial's SDC U.S. New Issues database. They range from IPOs to offerings by seasoned firms, and include

\footnotetext{
${ }^{7}$ Agrawal and Chen's (2004) analysis of regulatory filings by U.S. broker-dealers shows that the larger brokers usually withhold their business-by-business revenue breakdown from public inspection.

${ }^{8}$ Ljungqvist, Marston, and Wilhelm (2004) use an event-time approach, focusing on analyst behavior around the dates companies issue debt and equity securities. This allows them to use each company's contribution to a bank's underwriting fee revenue as an additional proxy for investment banking pressure. In our calendar-time framework, this variable would be zero in most firm quarters, as few companies issue securities at any given point in time.

${ }^{9}$ All results are robust to using shorter windows.
} 
both public and private offerings of every type of security.

Many companies are related so we form "corporate families" on the basis of SDC's "ultimate parent CUSIP” identifier. For example, AT\&T Corp is the parent of AT\&T Wireless, Lucent Technologies, Teligent, etc. Often, but not always, it is the corporate parent that is publicly traded and so shows up in our Spectrum dataset. We measure the strength of the relationship between a given bank and the corporate parent by giving the parent credit for any relationships that tie any of its "subsidiaries" to the bank. ${ }^{10}$ In cases where it is a subsidiary rather than the parent that is publicly traded and therefore included in Spectrum, we measure the strength of the relationship at the subsidiary level. Finally, occasionally a parent is not publicly traded and the subsidiary has no underwriting relationships for lack of transactions. In these cases, we let the subsidiary "inherit" the parent's relationships. Our results are not sensitive to these coding choices.

In computing the relationship variables, we allow banks to inherit their predecessors' relationships. For instance, after its merger in May 1997, Morgan Stanley Dean Witter is treated as having relationships with both Dean Witter's and Morgan Stanley's former clients.

As Table 1 shows, the average bank underwrote $10.7 \%$ and $4.1 \%$ of the average company's equity and debt offerings by value, respectively, over the prior five years. Reflecting the fact that relationships are highly concentrated (so that most companies have no relationship with a given bank publishing research about their stocks), the median relationship measures are zero. Conditional on having a relationship, the average company used the same bank as lead manager to raise $87.8 \%$ of its prior equity and $49.1 \%$ of its prior debt proceeds. This indicates that debt relationships are considerably less exclusive than equity relationships.

\subsection{Analyst Characteristics}

We construct four analyst characteristics that aim to control for reputation-related career concerns. The first is based on institutional investors' evaluations reflected in the annual Institutional Investor

\footnotetext{
10 "Subsidiary" is meant to include any form of relationship resulting in SDC grouping the company in a corporate family.
} 
analyst rankings. We define a dummy to equal 1 if analyst $i$ covering stock $k$ was an all-star (i.e., ranked as a top-three or runner-up analyst in her industry) just prior to quarter $t$. For example, since rankings are published annually in October, we use the October 1994 rankings for the four quarters ending in December 1994-September 1995. Descriptive statistics are provided in Table 1. Nearly a third of recommendations in the sample $(29.2 \%)$ are by all-star analysts.

Second, assuming analyst reputation derives, at least in part, from forecasting ability, we measure relative forecast accuracy as in Hong and Kubik (2003). ${ }^{11}$ Table 1 reveals that this averages around a half, with a distribution similar to that reported by Hong and Kubik.

Third, we measure seniority as the number of years since an analyst first appeared in the $\mathrm{I} / \mathrm{B} / \mathrm{E} / \mathrm{S}$ earnings or recommendations files. Hong et al. (2000) find that analysts are less bold early in their careers. The average analyst has spent 6.9 years in the industry, with a range from zero to 19 years.

Finally, Jobmove $e_{i, t}$ is a dummy equaling one if analyst $i$ moved from one brokerage to another in quarter $t$, and $1 / 2,1 / 3,1 / 4$ in the next three quarters. Since banks differ in their client relationships, and if underwriting pressure and brokerage pressure are a strong influence on analyst behavior, we would expect analysts to adopt a set of "house biases" after they move to a new employer and reinitiate coverage. We take care to code only "moves" associated with a change of employer, excluding cases where the analyst's I/B/E/S broker code changes due to a merger between two brokers. Analysts regularly change jobs. Not counting bank mergers, 541 of the 3,313 analysts employed at our sample banks (16.3\%) change employer between 1994 and 2000.

\subsection{Analyst Recommendations}

$\mathrm{I} / \mathrm{B} / \mathrm{E} / \mathrm{S}$ codes recommendations from 1 (strong buy) to 5 (sell). ${ }^{12}$ We reverse the ordering so that

\footnotetext{
${ }^{11}$ We compute the absolute forecast error of each analyst $i$ covering firm $k$ in year $t$ as the difference between the analyst's most recent forecast of year-end earnings per share (issued between January 1 and July 1 of that year) and subsequent realized earnings, scaled by price (measured as of the prior December). Absolute forecast errors are then scaled so that the most accurate analyst scores 1 and the least accurate zero. The analyst's relative forecast accuracy in year $t$ then is her average score across the $k$ stocks she covers over years $t-2$ to $t$.

${ }^{12}$ Strong buys account for $29.4 \%$ of recommendations; $37.2 \%$ are buy recommendations, $30.3 \%$ are hold recommendations, $1.5 \%$ are underperform recommendations and $1.6 \%$ are sell recommendations.
} 
larger numbers indicate more positive recommendations. New, reiterated, or changed

recommendations arrive, and are recorded by $\mathrm{I} / \mathrm{B} / \mathrm{E} / \mathrm{S}$, irregularly and, compared to earnings forecasts, relatively infrequently. Thus, the most recent recommendation for a given firm by a given bank will not necessarily correspond in time with the most recent recommendation from a competing bank. We resolve the time-matching problem by focusing on the most recent recommendation recorded in the one-year window ending in quarter $t$. This implicitly assumes that, say, a three-quarter-old recommendation is still current in quarter $t$, given the absence of a revision.

We normalize recommendations by subtracting the "consensus." This ensures comparability across companies and provides a natural measure of an individual analyst's optimism (or bias). We measure consensus as the median recommendation among analysts from all banks covering company $k$ in the prior one-year window, whether or not they are sample banks. ${ }^{13}$ By construction, relative recommendations range between -4 and +4 . Positive values correspond to relatively optimistic recommendations. Not surprisingly, the average and median relative recommendations in our sample are very nearly zero. $94.7 \%$ of all relative recommendations lie between -1 and +1 , so we are mostly capturing recommendations that are a notch above or below the consensus.

We also control for three aspects of analyst recommendations. Initiation $_{i, k, t}$ is a dummy set equal to one in the first quarter in which analyst $i$ publishes a report on company $k \cdot{ }^{14}$ Around a tenth of recommendations are initiations. Seasoning ${ }_{i, k, t}$ is defined as the natural logarithm of one plus the time (in quarters) since initiation. This captures how long the analyst has covered the stock, and averages 9.9 quarters. We also control for the number of stocks the analyst covers in a given quarter (as judged by unique I/B/E/S CUSIPs), which averages 13 stocks (median: 11). One utilities analyst is credited with covering 115 stocks in 1999 while working at BT Alex. Brown and then Deutsche Bank, partly through publishing sector reports.

\footnotetext{
${ }^{13}$ Our results are robust to the following alternative ways to measure the consensus: subtracting the mean recommendation; defining the peer group to include only sample banks (rather than all banks); or taking as the consensus the recommendations of analysts from firms that do not underwrite security offerings (such as Sanford Bernstein).

${ }^{14}$ Initiations that occurred before 1994 are identified from the I/B/E/S earnings forecast database.
} 


\subsection{Analyst Forecast Accuracy}

In addition to analysts' recommendations, we also examine the effect of institutional ownership on analysts' forecast accuracy. We expect analysts who are interested in boosting their human capital to strive for greater accuracy in stocks that are predominantly held by institutional investors. We measure forecast accuracy as the absolute error of fiscal year-end forecasts relative to subsequently realized earnings, scaled by the standard deviation of forecast errors: abs(realized earnings - forecast earnings)/st.dev. (Scaling instead by the mean forecast error strengthens our results substantially.) Following Brown and Mohammad (2001), we then normalize this measure by subtracting the absolute error of the consensus forecast (taken to be the median forecast).${ }^{15}$ This normalization has two desirable effects. First, it makes forecast accuracy comparable across companies. For example, a forecast error of two standard deviations indicates relatively high accuracy if the consensus forecast is off by three standard deviations, but not if the consensus forecast is off by one standard deviation. Second, the normalization corrects for the natural tendency of forecast errors to decline towards the fiscal year-end: As the analyst's forecast becomes more accurate over the fiscal year, so does the consensus forecast, leaving the difference stationary over the course of the fiscal year.

As Table 1 shows, the mean and median forecast errors relative to consensus are around zero. The best analysts beat the consensus forecast by a little over four standard deviations, while the worst analysts are off by nearly five standard deviations relative to the consensus.

\section{Analyst Recommendations}

\subsection{The Effect of Institutional Ownership on Analyst Recommendations}

Table 2 reports the results of estimating equation (1). The model shown in column (1) is estimated using a panel GLS regression with random analyst effects. Our proxies for investment banking and brokerage pressure are significantly and positively related to analyst recommendations: Both strong

\footnotetext{
${ }^{15}$ This is similar in spirit to Hong and Kubik's (2003) "relative forecast error" variable described in Section 3.6. Note how the two variables differ. "Relative forecast accuracy" is an analyst characteristic describing the average accuracy of her forecasts across the stocks she has covered over the past three years, relative to other analysts. In contrast, "analyst forecast accuracy" as defined here measures the accuracy of analyst $i$ 's forecast for firm $k$ in quarter $t$, relative to consensus.
} 
equity and debt underwriting ties with the analyst's bank (as proxied by the bank's share of the company's underwriting mandates over the prior five years) and the size of the bank's brokerage business (as proxied by the log annual number of registered representatives) are associated with significantly more aggressive analyst behavior.

This greater optimism is tempered by the bank's reputation: Analysts employed at banks whose underwriting clients are more loyal and that have large equity underwriting market shares issue significantly less aggressive recommendations. These findings mirror those of Ljungqvist, Marston, and Wilhelm (2004), who interpret them as indicating that analysts employed by more reputable banks face less pressure to inflate their recommendations.

Bank reputation is not the only moderating force. Analysts in our sample issue relatively more conservative recommendations for stocks with greater institutional ownership. Thus, for a given analyst, we find that the analyst behaves differently across the companies she covers, with more aggressive recommendations for relationship clients and less aggressive recommendations for companies that are highly visible to the institutional investor community. These results suggest that institutional investors serve as a moderating influence on a sell-side analyst's incentives, presumably through the institutions' ability to evaluate the analyst (in public surveys) and through the institutions' ability to choose which brokerage firms to allocate their trading commissions to.

The traditional proxies for analyst reputation, on the other hand, do not appear to temper analyst optimism in this specification. Neither the analyst's Institutional Investor ranking nor her seniority has any effect on her recommendations. (This could be driven by the inclusion in column (1) of random analyst effects, and indeed once we switch to random firm effects, we find that all-star analysts issue less aggressive recommendations.) Greater relative forecast accuracy, on the other hand, is associated with significantly above-consensus recommendations. This is consistent with the spirit of Hong et al. (2000) insofar as analysts who are usually accurate can credibly make bolder recommendations. When initiating coverage, analysts issue recommendations that are indistinguishable from the 
consensus, possibly because the uncertainty involved in initiating coverage leads to herding behavior (Trueman, 1994; Welch, 2000). Recommendations become significantly more favorable the longer the analyst has followed the stock, perhaps because the analyst becomes too close to management and loses objectivity over time ("capture"). Alternatively, the coefficient may capture the tendency of analysts to continue covering stocks that are performing well and dropping stocks that are performing poorly. ${ }^{16}$ The negative and significant coefficient estimated for jobmove suggests that far from adopting a set of house biases as they move to a new employer, analysts in fact reinitiate coverage with relatively conservative recommendations. Analysts covering more stocks are associated with less aggressive recommendations.

Finally, column (1) also controls for company characteristics. Companies that are covered by more analysts receive relatively more favorable recommendations. This result may be due to selection. Analysts tend to cover firms about which they have positive views (McNichols and O'Brien, 1997). Firms that attract more analysts would then be those that analysts view more favorably. The evidence regarding issuers' capital-raising histories is mixed. More active debt issuers receive more favorable recommendations, consistent with the interpretation that greater fee-generating capacity may lead investment bankers to pressure analysts into inflating their opinions. On the other hand, analysts are significantly more conservative about more active equity issuers, which does not support this interpretation. Perhaps frequent equity issuance is simply viewed as a negative by this set of analysts, similar to the often negative announcement effect upon seasoned equity issues. ${ }^{17}$ Company size, as proxied by log market capitalization, has no effect on analyst recommendations. (This remains the case if we measure company size using log sales instead.)

To check the robustness of our results, we also employ several other model specifications. The model shown in column (2) is estimated using the Fama-MacBeth approach. That is, we estimate 28

\footnotetext{
${ }^{16}$ The result that a given analyst's recommendations become more favorable over time contrasts with Bradley, Jordan, and Ritter's (2004) finding that average post-IPO recommendations became less favorable over time in the late 1990s.

${ }^{17}$ This result contrasts with the positive relation found by Ljungqvist, Marston, and Wilhelm (2004) in the context of an event-time analysis of analyst behavior around equity issuance dates.
} 
separate least-squares regressions of equation (1) (one for each possible quarter) and report the averaged coefficients. The standard errors are obtained from the time series variation of the coefficients. Each regression includes analyst fixed effects, which precludes us (in this model) from including analyst and bank characteristics such as Institutional Investor ranking and lagged underwriting market share, as these are constant for a given analyst and bank within a quarter.

Comparing the results of the Fama-MacBeth model in column (2) to those of the panel GLS model with random analyst effects in column (1) shows that the coefficient estimates and significance levels in columns (1) and (2) are very similar. We continue to find that relative recommendations are more conservative for stocks with greater institutional ownership, and the relevant coefficient estimates in (1) and (2) are statistically identical.

The model shown in column (3) re-estimates model (1) using a panel GLS regression with random firm (rather than analyst) effects. We expect differences between the two models to the extent that a variable correlates more with one source of heterogeneity than with the other. The core results are unchanged: The coefficient estimated for institutional ownership continues to be negative and highly significant. It is statistically of the same magnitude as in model (1), suggesting that our inference is unaffected by how we model the unobserved heterogeneity. There are, however, two interesting changes among the controls. First, we find that all-stars are significantly more conservative than other analysts in the random firm effects specification, consistent with the hypothesis that reputational concerns mitigate conflicts of interest among analysts. Second, more senior analysts issue significantly more aggressive recommendations when we include firm effects, consistent with prior results suggesting that analysts become bolder when their careers are better established (Hong et al., 2000).

Our dependent variable in models (1) through (3) is based on a transform of an ordinal scale (the five recommendation levels less the consensus recommendation). Thus, a potentially better approach than random-effects GLS regressions may be to estimate an ordered probit model. The ordered probit shown in column (4) models a three-level choice: Issuing a recommendation that is below, at, or above 
consensus. ${ }^{18}$ Note that ordered probits cannot accommodate random (or any other) effects.

Nevertheless, our results remain qualitatively unchanged, and the economic magnitude of the effect of institutional holdings is considerable: A one standard deviation decrease in institutional holdings is associated with a six percentage point increase from the $24 \%$ unconditional likelihood that the analyst will issue an above-consensus recommendation. This suggests analysts face a trade-off between boosting their banks' brokerage and investment banking businesses, and the repercussions of such behavior on their human capital through institutional investors' views of the analysts' performance.

\subsection{Endogenous Coverage Selection}

Might our results be due to analysts strategically choosing to publish research about companies that are held primarily by institutional investors? As noted in Section 2.4 , it is not computationally feasible to estimate a Heckman correction in a random-effects model with a sample size as large as ours. Instead, we attempt to correct for possible selection bias indirectly. First, to the extent that analysts at our (relatively large) sample banks have little discretion with respect to covering the very largest companies in their sectors, we expect selection bias to play little or no role when we restrict the sample to the five largest firms in each three-digit SIC code, ranked quarterly by sales. ${ }^{19}$ The results are shown in columns (1) and (2) of Table 3, using analyst and firm random effects, respectively. The results are little changed from those reported for the whole sample in Table 2, and the coefficients estimated for institutional ownership are, if anything, a little larger in absolute magnitude (i.e., more negative).

Our second approach is to model the coverage decision directly and correct the recommendations regression for self-selection following Heckman (1979) but ignoring any random effects. For this purpose, we first create a dataset containing every possible bank-firm quarter, whether or not an analyst at a given bank covered a given firm that quarter. After deleting quarters before a firm enters or after it leaves the sample, and quarters after a bank disappears due to a merger, we are left with

\footnotetext{
${ }^{18}$ Simple probits of the choice to issue above-consensus recommendations (not shown) yield qualitatively similar results.

${ }^{19}$ We obtain similar (and no weaker) results if we use the ten largest firms in each industry, or if we use four-digit SIC codes to define industries.
} 
$3,994,209$ observations. There is active coverage in 224,404 bank-firm quarters $(5.6 \%$ of the potential total), confirming that analysts are highly selective in choosing which stocks to cover.

To instrument the coverage decision, we follow Ljungqvist, Marston, and Wilhelm (2004). The broader a bank's existing coverage of company k's Fama-French (1997) industry, the lower the cost of covering company $k$ 's stock, and so the more likely it is that the bank's analyst will publish research about company $k$. In addition, the coverage equation also includes all our variables that are not analystspecific (since in the absence of coverage, there is no specific analyst whose characteristics we can measure). The results, shown in the third column of Table 3, confirm that analysts are more likely to cover a stock the more of the company's Fama-French industry they already cover. Coverage is also more likely for the bank's relationship clients, the larger the brokerage workforce, at banks with more loyal investment banking clients, the larger is institutional ownership in the stock, the more analysts at other banks cover the stock, and the larger the company (in terms of market capitalization). Somewhat surprisingly, larger equity underwriters are less likely to provide coverage, all else equal, and the more active debt and equity issuers are also less likely to be covered.

The final column of Table 3 reports the results of estimating equation (1) after correcting for endogenous selection. There is no inverse Mill's ratio (“Heckman's lambda”) in the model as we estimate the maximum-likelihood version of Heckman (1979). The results mirror those shown in Table 2. In particular, the coefficient estimated for institutional ownership continues to be negative and significant, and it is statistically indistinguishable from the Table 2 coefficients which control for unobserved firm or analyst heterogeneity but ignore endogenous selection. Thus, while institutional ownership indeed affects the coverage decision positively, we continue to find that it moderates analyst behavior even after controlling for selection bias. One plausible reason for the apparent robustness of our results to endogenous coverage selection is that the selection process may be relatively constant over time, so that the inclusion of random analyst effects removes the main source of bias. 


\subsection{The Composition of Institutional Ownership}

So far, we have shown that the level of institutional ownership acts as an important constraint on analyst behavior. We now investigate the conjecture that the number of institutions that invest in a stock affects how binding a constraint institutional ownership is. The more institutional investors invest in the stock, the costlier it may be for an analyst to bias her recommendations. The first two columns of Table 4 replace institutional stock holdings with the log number of institutional investors listed in Spectrum. Controlling for random firm effects, column (2) supports our conjecture: A larger number of institutional investors is associated with significantly less aggressive recommendations. However, this variable is not significant when we control for random analyst effects (see column (1)).

Columns (3) and (4) explore a slightly different specification, dividing institutional ownership by the number of investors to measure the average size of institutional holdings in a firm. Whether we control for random analyst or firm effects, we find that companies with larger average institutional holdings are associated with significantly more conservative recommendations. This too is consistent with a moderating role for such investors.

If analysts take the presence of institutional investors into account when formulating their recommendations, it seems plausible that larger investors exert more influence. Funds under management directly affect the weighting an investor's votes receive in the annual Institutional Investor poll, and size also likely correlates with the amount of trading commissions the investor can allocate among brokerage firms. Hence we expect analysts to be more conservative when stock $k$ is primarily owned by large institutions.

To investigate this hypothesis, we first identify the 100 largest institutions listed in Spectrum, judged by the dollar value of all their equity holdings in the last quarter of 1993. Then we check how many of these Top 100 investors have stakes in each sample firm in each quarter, and record the aggregate size of their stakes. The average sample firm has 33.9 Top 100 investors owning $26.9 \%$ of its equity in aggregate, or $1.1 \%$ each on average. In addition, the average firm has 127.4 smaller 
institutional investors owning $26 \%$ of its equity in aggregate, or $0.6 \%$ each on average. ${ }^{20}$

In Table 5, we split overall institutional holdings into those of Top 100 investors and those of smaller institutional investors. We expect top-ranked investors to exert more of a moderating influence, all else equal. In column (1), where we include analyst effects, the coefficient for the holdings of Top 100 investors is more than twice the size of the coefficient for the holdings of smaller investors. Both coefficients are significantly different from zero, but more importantly, they are also significantly different from each other $(p=0.02)$. This is consistent with the interpretation that analyst behavior is moderated more by the presence of Top 100 investors than of smaller institutions. The random firm effects specification in column (2) reveals a similar ordering, but there the coefficients are not statistically different from each other.

The final two columns of Table 5 investigate the effect of the size of the average holdings of Top 100 and smaller investors. Recall from Table 4 that a decrease in the average institutional holding size reduces the moderating effect of institutional ownership. We now partition institutional holdings by investor size. Interestingly, whether we use analyst or firm effects, it is only Top 100 investors' holdings that have any effect on analyst behavior: Recommendations are significantly more conservative, the larger the average Top 100 investor's equity stake in the firm in question.

\section{Analyst Forecast Accuracy}

To this point we have provided evidence that institutional investor ownership in a stock influences analysts' recommendations. A related question is whether analysts strive for greater accuracy in stocks predominantly held by institutional investors. To examine this question, we regress our measure of analyst forecast accuracy (the scaled absolute forecast error relative to consensus) on institutional ownership, underwriting relationships, and bank, firm, and analyst characteristics. The results, presented in Table 6, show that analysts are more accurate than consensus (i.e., have smaller absolute forecast errors) when their banks have strong equity underwriting relationships with the company in

\footnotetext{
20 "Smaller" is a relative term. Only institutions with at least $\$ 100$ million in equity holdings are required to file $13 \mathrm{f}$ reports.
} 
question, whether we control for unobserved analyst or firm heterogeneity (neither of which appears to be present). This could indicate that such relationships provide analysts with a better understanding of the company concerned. Debt relationships, which anyway appear weaker in our data set, do not have a corresponding effect. Analysts employed at larger brokerages are more accurate, all else equal. Taken together, there is little evidence that analysts jeopardize their forecast accuracy when bowing to investment banking or brokerage pressure to inflate their recommendations.

They do, however, appear to respond to the presence of institutional investors: For a given analyst, forecast errors are significantly smaller in those stocks predominantly held by institutional investors. (Since we measure forecast errors relative to consensus, this does not simply mean that institutional investors choose to invest in stocks that are relatively easy to forecast.)

Among the controls, the main analyst characteristic that determines forecast accuracy is Hong and Kubik’s (2003) relative forecast accuracy variable. Analysts with a history of relatively accurate forecasts across the stocks they have covered in the past are associated with relatively smaller forecast errors on individual stocks in the future. (Dropping this variable does not affect our results.) Counter to previous evidence by Stickel (1992), we find that all-star analysts are no better at forecasting earnings than are other analysts. On the other hand, more senior analysts - perhaps surprisingly - are significantly worse. Stocks covered by many analysts and those of active equity issuers are associated with larger forecast errors, all else equal, while companies with larger equity market capitalizations have smaller forecast errors, all else equal.

\section{Analysts' Reactions to Bad News}

Lin, McNichols, and O’Brien (2003) show that following equity issues, affiliated analysts take longer to eventually downgrade their recommendations than do unaffiliated analysts. They interpret this behavior as reluctance to issue bad news (in the form of downgrades) for relationship clients. We examine whether affiliated analysts continue to reappraise stocks in a less timely fashion than unaffiliated analysts once we control for the moderating influence of institutional investors. 
Our approach differs somewhat from Lin, McNichols, and O’Brien's (2003), as our dataset includes all firm-quarters in the intersection of Spectrum and $\mathrm{I} / \mathrm{B} / \mathrm{E} / \mathrm{S}$ and so is not restricted to firms raising equity capital. We begin by identifying in CRSP all one-day split-adjusted stock price falls during 1994-2000 that exceed (in absolute value) X times the company's prior-year standard deviation of daily returns, where $X=4$ or 5 . These are unusually large price drops, and they are likely, at least in part, driven by bad news. ${ }^{21} \mathrm{We}$ are agnostic about what the bad news might be.

For $X=4(X=5)$, there are $27,804(15,279)$ events with price drops averaging $-17.9 \%(-21.7 \%)$ in a single day. ${ }^{22}$ We merge the CRSP price drop events into our Spectrum-I/B/E/S dataset, requiring the analyst to have issued at least one recommendation during the 365 days prior to the price drop. This allows us to track the reaction to the price drop for all analysts who are actively covering a stock. Not surprisingly, analysts react to price drops by downgrading the stock: Over the first year after a $4 \mathrm{X}$ price drop, for instance, downgrades outnumber upgrades two-to-one. The median analyst downgrades the stock by one notch from the average "buy" recommendation.

Focusing on revisions during the first post-event year, the average analyst takes 119.5 days to change her recommendation after a $4 \mathrm{X}$ price drop. The reaction times of affiliated and unaffiliated analysts differ by a mere 1.6 days (defining unaffiliated analysts as those whose banks had no underwriting relationships with the company during the prior five years). ${ }^{23}$ Clearly, this estimate contrasts markedly with Lin, McNichols, and O'Brien's (2003) study of post-equity offering behavior, though being unconditional it does not control for other determinants of reaction times. Therefore, we turn to estimating conditional models of the cross-section of reaction times:

$$
\ln T_{i, k}=\pi \Delta P_{k}+\kappa C_{k}+\lambda I_{i}+\omega R_{i, k}^{j}+\varphi B_{i}^{j}+\mu_{i, k}
$$

where $T_{i, k}$ is the time to analyst $i$ issuing a new recommendation following a large drop in company $k$ 's

\footnotetext{
${ }^{21}$ Occasionally, companies experience a string of several days of large price drops. These are presumably not independent events, so we require consecutive events to be at least 91 calendar days apart. This restriction does not affect our results.

${ }^{22}$ Using market-return adjusted price drops does not affect our results.

${ }^{23}$ Allowing analysts more than a year to react to the event does not change this conclusion.
} 
share price, $\Delta P_{k}$ is the one-day percentage change in share price associated with the event, and $C_{k}, I_{i}$, $R_{i, k}^{j}$, and $B_{i}^{j}$ are the aforementioned vectors of company, analyst, relationship, and bank characteristics, respectively. We estimate equation (3) using either the set of $4 \mathrm{X}$ or $5 \mathrm{X}$ price drops. Each model includes analyst fixed effects to control for unobserved heterogeneity. Note that we continue to ignore analysts employed at non-sample banks.

The results are reported in Table 7. Column (1) focuses on $4 \mathrm{X}$ price drops. The regression explains $11.4 \%$ of the variation in reaction times. The coefficient estimated for $\Delta P_{k}$ is large and positive, suggesting that analysts revise their recommendations faster, the larger the price drop (i.e., the smaller $\Delta P_{k}$ ). Economically, the effect is large: A one standard deviation increase in the size of the price drop is associated with a 17.6 day reduction in the reaction time.

Among the control variables, we note that all-star analysts react significantly faster, consistent with reputation considerations, while more senior analysts, and analysts who have covered the stock for a longer time, have longer reaction times. These effects are large in economic magnitude: One standard deviation increases in seniority and seasoning lead to increases in reaction times of 40.8 and 19 days, respectively. Curiously, analysts who cover fewer companies react significantly more slowly.

Company characteristics make little difference to reaction times; larger firms (by equity market capitalization) are re-rated faster but this is significant only in the column (1) specification. Analysts at banks with more loyal corporate clients react significantly faster to price drops, consistent with our earlier interpretation that such banks have less need to bias their analysts' behavior. The bank's underwriting market share, used to proxy for general bank reputation, does not affect reaction times.

Controlling for these factors, we find no evidence that the strength of underwriting relationships affects reaction times significantly. This confirms our unconditional finding and contrasts with the result of Lin, McNichols, and O'Brien (2003). ${ }^{24}$ In an attempt to replicate their result, we have

\footnotetext{
${ }^{24}$ These results also contrast somewhat with Barber, Lehavy, and Trueman (2004) who conclude that investment banks are more reluctant to downgrade buy recommendations than are independent research firms.
} 
estimated alternative specifications that exclude one or more of our controls. When we exclude company characteristics, we do find that stronger equity underwriting relationships are associated with less timely recommendation revisions ( $p=0.038$; see column (2)).

More importantly, both specifications show that stocks with larger institutional ownership are rerated significantly faster. Thus, across the stocks an analyst covers, price drops are followed more quickly by a reassessment when the stock has a large institutional following. Though not shown, this continues to be the case when we measure institutional following in the manner of Tables 4 and $5 .^{25}$

Columns (3) and (4) replicate this analysis on the sample of $5 \mathrm{X}$ price drops. Our main conclusions are unaffected, except that excluding company characteristics in column (4) is insufficient to make the coefficient for underwriting relationships significant. The economic effect of institutional ownership is larger in the $5 \mathrm{X}$ sample than in the $4 \mathrm{X}$ sample, with a one-standard deviation fall in institutional ownership increasing reaction times by 4.3 days ( $8.3 \%$ of the mean reaction time in the $5 \mathrm{X}$ sample).

\section{Conclusions}

We examine how competing influences on sell-side analysts' incentives affect three aspects of analyst behavior: The optimism revealed in the level of investment recommendations relative to consensus, the accuracy of earnings forecasts, and the timeliness with which analysts react to bad news affecting companies they cover. Analysts face pressure to provide favorable opinions on their employers' investment banking clients and to stimulate brokerage business, yet institutional investors value unbiased research. Because of their dependence on institutional investors for performance ratings and trading commissions, we conjecture that analysts are less likely to succumb to investment banking or brokerage pressure in stocks that are highly visible to their institutional investor constituency.

Consistent with previous research, we find greater relative optimism in analyst recommendations

\footnotetext{
${ }^{25}$ Why would institutional investors want analysts to downgrade the securities they own? As the previously cited October 2004 Institutional Investor article shows, institutions most value industry knowledge, integrity/professionalism, and accessibility/responsiveness. Timely downgrades in recommendations are consistent with these traits. Further, the article highlights specific instances of downgrades that institutions appreciated, e.g., "Clients were especially pleased with the 41year-old analyst's downgrades of newsprint producers."
} 
for firms that have an existing investment banking relationship with the firm. We also document that analysts employed at banks with larger brokerage businesses issue more aggressive recommendations. However, this greater optimism is offset by two countervailing influences. Consistent with Ljungqvist, Marston, and Wilhelm (2004), we find a negative relation between analysts' optimism and proxies for the employing bank's reputational capital and the loyalty of the bank's corporate clients. Equally important, we show that analysts issue significantly less aggressive recommendations, strive for greater forecast accuracy, and incorporate bad news more quickly, for firms with larger institutional investor presence. Thus, the potential conflicts of interest in the production of investment research stemming from the competing roles sell-side analysts play in financial markets are moderated by the investment bank's reputation and the presence of institutional investors.

These results echo evidence that institutional investors can influence corporate decisions (e.g., Hartzell and Starks, 2003; Parrino, Sias, and Starks, 2003). However, we do not argue that institutional investors are engaged in explicitly monitoring analysts. Rather, it is the fact that institutions are the primary customers of the analysts' services that provides an incentive mechanism for the analysts.

Our findings imply that firms served by the most reputable investment banks and held primarily by institutional investors have less optimistically-biased recommendations, more accurate forecasts and more timely recommendation revisions than do firms employing smaller investment banks and held primarily by retail investors. We also know from previous results that institutional investors appear to recognize the bias in analyst forecasts, while retail investors do not (e.g., Iskoz, 2003; Malmendier and Shanthikumar, 2004). Taken together, these results suggest that retail investors may benefit from the separation of research from investment banking agreed in the New York State Attorney General's 2002 Global Settlement with the ten largest investment banks. However, to the extent that the conflicts of interest were more severe among the smaller investment banks, which are not subject to the settlement and the collective $\$ 1.4$ billion fine, the overall welfare effects of the Global Settlement remain an open question. 


\section{References}

Agrawal, Anup and Mark A. Chen, 2004, Analyst conflicts and research quality, unpublished working paper, University of Alabama and University of Maryland.

Antweiler, Werner, 2001, Nested random effects estimation in unbalanced panel data, Journal of Econometrics 101, 295-313.

Barber, Brad, Reuven Lehavy, and Brett Trueman, 2004, Comparing the stock recommendation performance of investment banks and independent research firms, unpublished working paper, University of California - Davis, University of Michigan, and University of California - Los Angeles.

Boni, Leslie, and Kent Womack, 2003, Analysts, industries and price momentum, unpublished working paper, Tuck School of Business, Dartmouth.

Bradley, Daniel, Bradford Jordan, and Jay Ritter, 2004, Analyst behavior following IPOs: The "Bubble Period" evidence, unpublished working paper, Clemson University, University of Kentucky, and University of Florida.

Brown, Lawrence, and Emad Mohammad, 2001, Profiting from predicting individual analyst earnings forecast accuracy, unpublished working paper, Georgia State University.

Chen, Xia, 2004, Analysts' affiliation, ranking, and the market reaction to stock recommendations for IPOs, unpublished working paper, University of British Columbia.

Clarke, Jonathan, Ajay Khorana, Ajay Patel, and P. Raghavendra Rau, 2004a, Do leopards change their spots? The impact of analyst job changes on stock coverage, recommendations, and deal flow, unpublished working paper, Purdue University.

Clarke, Jonathan, Ajay Khorana, Ajay Patel and P. Raghavendra Rau, 2004b, The good, the bad and the ugly? Differences in analyst behavior at investment banks, brokerages and independent research firms, unpublished working paper, Purdue University.

Cowen, Amanda, Boris Groysberg, and Paul M. Healy, 2003, Which types of analyst firms make more optimistic forecasts? Unpublished working paper, Harvard Business School.

Das, Somnath, Carolyn B. Levine, and K. Sivaramakrishnan, 1998, Earnings predictability and bias in analysts' earnings forecasts, The Accounting Review 73, 277-294.

Dugar, Amitabh, and Siva Nathan, 1995, The effects of investment banking relationships on financial analysts' earnings forecasts and investment recommendations, Contemporary Accounting Research 12, 131-160.

Fama, Eugene, and Kenneth French, 1997, Industry costs of equity, Journal of Financial Economics 43, 153-194.

Fama, Eugene F., and James MacBeth, 1973, Risk, return, and equilibrium: Empirical tests, Journal of Political Economy 71, 607-636. 
Francis, Jennifer and Donna Philbrick, 1993, Analysts' decisions as products of multi-task environment, Journal of Accounting Research 31, 216-230.

Frankel, Richard M., S.P. Kothari, and Joseph Weber, 2004, Determinants of the informativeness of analyst research, Unpublished working paper, MIT.

Hartzell, Jay, and Laura Starks, 2003, Institutional investors and executive compensation, Journal of Finance 58, 2351-2374.

Heckman, James J., 1979, Sample selection bias as a specification error, Econometrica 47, 153-162.

Hong, Harrison, and Jeffrey D. Kubik, 2003, Analyzing the analysts: Career concerns and biased earnings forecasts, Journal of Finance 58, 313-351.

Hong, Harrison, Jeffrey D. Kubik, and Amit Solomon, 2000, Security analysts' career concerns and the herding of earnings forecasts, RAND Journal of Economics 31, 121-144.

Institutional Investor, 2004, The best analysts of the year, Vol. 38, Issue 10 (October), 66-95.

Irvine, Paul, 2003, Analysts' forecasts and brokerage-firm trading, Accounting Review, forthcoming.

Iskoz, Sergey, 2003, Bias in underwriter analyst recommendations: Does it matter? Unpublished working paper, MIT.

Jackson, Andrew, 2003, Trade generation, reputation, and sell-side analysts, unpublished working paper, London Business School.

Jacob, John, Steve Rock, and David Weber, 2003, Do analysts at independent research firms make better earnings forecasts? Unpublished working paper, University of Colorado, Boulder.

Kolasinski, Adam and S.P. Kothari, 2004, Investment banking and analyst objectivity: Evidence from forecasts and recommendations of analysts affiliated with M\&A advisors, unpublished working paper, MIT.

Kothari, S.P., 2000, Discussion of "The relation between analysts' forecasts of long-term earnings growth and stock price performance following equity offerings", Contemporary Accounting Research 17, 33-39.

Lim, Terrence, 2001, Rationality and analysts' forecast bias, Journal of Finance 56, 369-385.

Lin, Hsiou-wei, and Maureen F. McNichols, 1998, Underwriting relationships, analysts' earnings forecasts and investment recommendations, Journal of Accounting and Economics 25, 101-127.

Lin, Hsiou-wei, Maureen F. McNichols, and Patricia O’Brien, 2003, Analyst impartiality and investment banking relationships, unpublished working paper, Stanford University. 
Ljungqvist, Alexander, Felicia Marston, and William J. Wilhelm, 2004, Competing for securities underwriting mandates: Banking relationships and analyst recommendations, Journal of Finance, forthcoming.

Malmendier, Ulrike, and Devin Shanthikumar, 2004, Are investors naïve about incentives? Unpublished working paper, Stanford University.

Matsumoto, D., 2002, Management's incentives to avoid negative earnings surprises, Accounting Review 77, 483-514.

McNichols, Maureen, and Patricia O'Brien, 1997, Self-selection and analyst coverage, Journal of Accounting Research 35, 167-199.

Megginson, William L., and Kathleen A. Weiss, 1991, Venture capitalist certification in initial public offerings, Journal of Finance 46, 879-903.

Michaely, Roni, and Kent L. Womack, 1999, Conflict of interest and credibility of underwriter analyst recommendations, Review of Financial Studies 12, 653-686.

Mikhail, Michael B., Beverly R. Walther, and Richard H. Willis, 1999, Does forecast accuracy matter to security analysts? Accounting Review 74, 185-200.

O'Brien, Patricia C., 1988, Analysts forecasts as earnings expectations, Journal of Accounting and Economics 187-221.

O’Brien, Patricia C., and Ravi Bhushan, 1990, Analysts following and institutional ownership, Journal of Accounting Research (Supplement), 55-76.

Parrino, Robert, Richard Sias, and Laura Starks, 2003, Voting with their feet: Institutional ownership changes around forced CEO turnover, Journal of Financial Economics 68, 3-46.

Richardson, Scott, Siew Hong Teoh, and Peter Wysocki, 2004, The walkdown to beatable analyst forecasts: The role of equity issuance and insider trading incentives, Contemporary Accounting Research 21, 885-924.

Stickel, Scott, 1992,Reputation and performance among security analysts, Journal of Finance 47, $1811-1836$.

Trueman, Brett, 1994, Analyst forecasts and herding behavior, Review of Financial Studies 7, 97-124.

Welch, Ivo, 2000, Herding among security analysts, Journal of Financial Economics 58, 369-396. 


\section{Table 1. Descriptive sample statistics}

The sample consists of 230,268 firm-analyst quarters, representing the intersection of the Spectrum $13 \mathrm{f}$ and I/B/E/S analyst recommendations datasets during the period 1994-2000. We exclude companies in SIC industries 6000-6999 (financial institutions, etc.) and 9000-9999 (government agencies, etc.), and 5,264 cases where analysts submit recommendations to $\mathrm{I} / \mathrm{B} / \mathrm{E} / \mathrm{S}$ anonymously.

\begin{tabular}{|c|c|c|c|c|c|c|}
\hline & Number & Mean & Std. dev. & Min & Median & Max \\
\hline no. of analysts covering stock & 230,268 & 5.6 & 3.9 & 1 & 5 & 36 \\
\hline company’s institutional ownership (\%) & 230,268 & 52.8 & 22 & 0 & 55.5 & 100 \\
\hline company's equity market capitalization $(\$ \mathrm{~m})$ & 229,990 & 6,645 & 21,900 & 0 & 1,218 & 602,000 \\
\hline company's equity proceeds prior 5 years $(\$ \mathrm{~m})$ & 131,399 & 320.7 & $1,102.1$ & 0.2 & 114.1 & 67,064 \\
\hline company's debt proceeds prior 5 years $(\$ \mathrm{~m})$ & 103,805 & 936.5 & $1,759.9$ & 0.2 & 330 & 43,633 \\
\hline bank's equity market share prior calendar year (\%) & 230,268 & 5.2 & 5 & 0 & 3.3 & 21.5 \\
\hline bank's loyalty index ( $\%$ of retained clients) & 230,268 & 62.2 & 16.8 & 0 & 64.6 & 100 \\
\hline number of registered representatives (i.e. brokerage employees) & 230,268 & 3,798 & 5,039 & 20 & 948 & 19,000 \\
\hline bank's share of company's equity deals prior 5 years (\%) & 230,268 & 10.7 & 29.9 & 0 & 0 & 100 \\
\hline bank's share of company's debt deals prior 5 years (\%) & 230,268 & 4.1 & 17.4 & 0 & 0 & 100 \\
\hline Institutional Investor "all-stars" ( $\%$ of recommendations) & 230,268 & 29.2 & & & & \\
\hline analyst's relative forecast accuracy $(\mathrm{x} 100)$ & 224,669 & 51.8 & 10.2 & 0 & 52.4 & 100 \\
\hline analyst's seniority (in years) & 230,268 & 6.9 & 4.8 & 0 & 6 & 19 \\
\hline jobmove ( $\%$ of analysts changing employer) & 230,268 & 1.5 & & & & \\
\hline relative recommendations & 230,268 & 0.015 & 0.729 & -4 & 0 & 4 \\
\hline initiation ( $\%$ of first-time recommendations) & 230,268 & 9.7 & & & & \\
\hline no. of quarters since analyst initiated coverage (seasoning) & 230,268 & 9.9 & 12.2 & 0 & 5 & 75 \\
\hline no. of stocks covered by analyst & 230,268 & 13.0 & 11.2 & 1 & 11 & 115 \\
\hline forecast accuracy (in standard deviations relative to consensus) & 238,418 & 0.030 & 0.818 & -4.2 & 0 & 4.9 \\
\hline
\end{tabular}




\section{Table 2. Determinants of relative recommendations.}

The dependent variable is relative recommendations, defined as analyst $i$ 's recommendation for company $k$ 's stock relative to consensus (the median recommendation of all other analysts covering firm $k$ ), where recommendations are coded from 1 (sell) to 5 (strong buy). By construction, relative recommendations lie between -4 and +4 with positive values denoting relatively aggressive recommendations. The models in columns (1) and (3) are estimated using random-effects GLS regressions, including either analyst or firm random effects, respectively. The Fama-MacBeth estimates in column (2) are based on the time-series average coefficients from 28 separate regressions (one for each possible quarter). The standard errors are obtained from the time series variation of the coefficient estimates. The ordered probit in the last column models a three-level choice: Issuing a below-, at- or above-consensus recommendation. (Note that ordered probits cannot accommodate fixed or random effects.) The ordered probit standard errors are clustered by analyst (i.e., observations are assumed to be independent across analysts but not necessarily within). To conserve space, intercepts effects are not shown. Standard errors are shown in italics underneath the coefficient estimates. We use ${ }^{* * *},{ }^{* *}$, and ${ }^{*}$ to denote significance at the $0.1 \%, 1 \%$, and $5 \%$ level (two-sided), respectively. The number of observations in all models is 224,404 . This is 5,864 short of the available number of firm-analyst quarters, due to missing observations on relative forecast accuracy, analyst seniority, and equity market capitalization.

\begin{tabular}{|c|c|c|c|c|}
\hline Dependent variable: Relative recommendations & $\begin{array}{l}\text { Random- } \\
\text { effects } \\
(1)\end{array}$ & $\begin{array}{c}\text { Fama- } \\
\text { MacBeth } \\
(2)\end{array}$ & $\begin{array}{l}\text { Random- } \\
\text { effects } \\
(3)\end{array}$ & $\begin{array}{c}\text { Ordered } \\
\text { probit } \\
(4)\end{array}$ \\
\hline \multicolumn{5}{|l|}{ Investment banking pressure (bank-company relationships) } \\
\hline \multirow[t]{2}{*}{ bank's share of company's equity deals prior 5 years } & $0.094^{* * *}$ & $0.094^{* * *}$ & $0.091^{* * *}$ & $0.135^{* * *}$ \\
\hline & 0.006 & 0.005 & 0.006 & 0.016 \\
\hline \multirow[t]{2}{*}{ bank's share of company's debt deals prior 5 years } & $0.106^{* * *}$ & $0.102^{* * *}$ & $0.141^{* * *}$ & $0.201^{* * *}$ \\
\hline & 0.009 & 0.009 & 0.009 & 0.026 \\
\hline \multicolumn{5}{|l|}{ Brokerage pressure (size of brokerage) } \\
\hline \multirow[t]{2}{*}{$\log$ no. of registered representatives } & $0.012^{* * *}$ & & $0.024^{* * *}$ & $0.037^{* * *}$ \\
\hline & 0.002 & & 0.001 & 0.005 \\
\hline \multicolumn{5}{|l|}{ Bank characteristics } \\
\hline \multirow[t]{2}{*}{ bank's loyalty index } & $-0.109^{* * *}$ & & $-0.174^{* * *}$ & $-0.273^{* * *}$ \\
\hline & 0.013 & & 0.011 & 0.048 \\
\hline \multirow[t]{2}{*}{ bank's equity market share prior calendar year } & $-0.448^{* * *}$ & & 0.010 & 0.059 \\
\hline & 0.059 & & 0.034 & 0.168 \\
\hline \multicolumn{5}{|l|}{ Institutional ownership } \\
\hline \multirow[t]{2}{*}{$\%$ institutional ownership } & $-0.072^{* * *}$ & $-0.066^{* * *}$ & $-0.087^{* * *}$ & $-0.089^{* * *}$ \\
\hline & 0.008 & 0.010 & 0.010 & 0.027 \\
\hline \multicolumn{5}{|l|}{ Analyst characteristics } \\
\hline \multirow[t]{2}{*}{$=1$ if analyst is an Institutional Investor "all-star" } & 0.003 & & $-0.026^{* * *}$ & -0.028 \\
\hline & 0.006 & & 0.004 & 0.024 \\
\hline \multirow[t]{2}{*}{ relative forecast accuracy } & $0.079^{* * *}$ & & 0.003 & 0.003 \\
\hline & 0.022 & & 0.015 & 0.076 \\
\hline \multirow[t]{2}{*}{$\log$ analyst's seniority (in years) } & 0.001 & & $0.018^{* * *}$ & 0.022 \\
\hline & 0.005 & & 0.003 & 0.013 \\
\hline \multirow[t]{2}{*}{$=1$ if analyst initiates coverage } & 0.000 & 0.000 & 0.009 & 0.015 \\
\hline & 0.006 & 0.007 & 0.006 & 0.011 \\
\hline \multirow[t]{2}{*}{ log no. of quarters since analyst initiated coverage (seasoning) } & $0.019^{* * *}$ & $0.018^{* * *}$ & $0.021^{* * *}$ & $0.037^{* * *}$ \\
\hline & 0.002 & 0.002 & 0.002 & 0.007 \\
\hline \multirow[t]{2}{*}{ jobmove (analyst changing employer) } & $-0.040^{* * *}$ & & $-0.061^{* * *}$ & $-0.086^{*}$ \\
\hline & 0.011 & & 0.010 & 0.034 \\
\hline \multirow[t]{2}{*}{$\log$ no. of stocks covered by analyst } & $-0.043^{* * *}$ & & $-0.037^{* * *}$ & $-0.047^{*}$ \\
\hline & 0.004 & & 0.003 & 0.020 \\
\hline
\end{tabular}


Table 2. Determinants of relative recommendations. (Continued)

\begin{tabular}{lcccc}
\hline \multicolumn{1}{c}{ Dependent variable: Relative recommendations } & $\begin{array}{c}\text { Random- } \\
\text { effects } \\
(1)\end{array}$ & $\begin{array}{c}\text { Fama- } \\
\text { MacBeth } \\
(2)\end{array}$ & $\begin{array}{c}\text { Random- } \\
\text { effects } \\
(3)\end{array}$ & $\begin{array}{c}\text { Ordered } \\
\text { probit } \\
(4)\end{array}$ \\
\hline Company characteristics & & & \\
log no. of analysts covering stock & $0.088^{* * *}$ & $0.084^{* * *}$ & $0.079^{* * *}$ & $0.122^{* * *}$ \\
& 0.004 & 0.006 & 0.004 & 0.012 \\
log company's \$ equity proceeds prior 5 years & $-0.007^{* * *}$ & $-0.007^{* * *}$ & $-0.006^{* * *}$ & $-0.009^{* * *}$ \\
& 0.001 & 0.001 & 0.001 & 0.002 \\
log company's \$ debt proceeds prior 5 years & $0.0019^{* *}$ & $0.0019^{*}$ & 0.0016 & 0.0012 \\
& 0.0006 & 0.0008 & 0.0009 & 0.0022 \\
log company's \$ equity market capitalization & 0.002 & 0.003 & 0.002 & 0.006 \\
& 0.001 & 0.002 & 0.002 & 0.004 \\
Random analyst effects & & & & No \\
Random firm effects & Yes & Yes & No \\
Fraction of variance due to random effects $(\rho)$ & No & No & Yes & No \\
Wald test: All coefficients $=0(F)$ & $14.7 \%$ & - & $3.3 \%$ & - \\
Overall GLS $R^{2} /$ pseudo $R^{2}$ & $118.5^{* * *}$ & - & $146.4^{* * *}$ & $32.0^{* * *}$ \\
& $1.2 \%$ & - & $1.4 \%$ & $0.7 \%$ \\
\hline
\end{tabular}


Table 3. Endogenous coverage selection.

The models in columns (1) and (2) replicate models (1) and (3) from Table 2 for the subsample of large firms, defined as the five largest firms in each three-digit SIC code, ranked quarterly by sales. Analysts arguably have less discretion with respect to covering the largest companies. Models (1) and (2) are estimated using random-effects GLS regressions, including either analyst or firm random effects, respectively. Model (3) uses the full sample and is estimated as a Heckman (1979) selection model. The first step models whether a given analyst $i$ covers a given stock $k$. This is the case in $5.6 \%$ of firm-analyst quarters. To instrument the choice, we include the fraction of firms in company $k$ 's Fama-French (1997) industry that analysts at $i$ 's bank cover at time $t$. The broader the bank's existing coverage of an industry, the lower the cost of covering company $k$ 's stock. This variable is uncorrelated with the second-step residuals. The second step of model (3) is estimated using the MLE version of Heckman (1979). To conserve space, intercepts effects are not shown. Standard errors are shown in italics underneath the coefficient estimates. We use ${ }^{* * *},{ }^{* *}$, and ${ }^{*}$ to denote significance at the $0.1 \%, 1 \%$, and $5 \%$ level (two-sided), respectively. The number of observations in models (1) and (2) is 80,813. The number of uncensored and censored observations in model (3) is 224,404 and $3,769,805$, respectively.

\begin{tabular}{|c|c|c|c|c|}
\hline \multirow[b]{2}{*}{ Dependent variable: } & \multicolumn{2}{|c|}{$\begin{array}{c}\text { Large firms only } \\
\text { Relative } \\
\text { recommendations }\end{array}$} & \multicolumn{2}{|c|}{ Heckman model } \\
\hline & $\begin{array}{l}\text { R } \\
\text { recomr } \\
\text { Analyst } \\
\text { effects } \\
\text { (1) }\end{array}$ & $\begin{array}{l}\text { ive } \\
\text { idations } \\
\text { Firm } \\
\text { effects } \\
\text { (2) }\end{array}$ & $\begin{array}{l}=1 \text { if } \\
\text { analyst } \\
\text { covers } \\
\text { stock }\end{array}$ & $\begin{array}{c}\begin{array}{c}\text { Relative } \\
\text { recommen- } \\
\text { dations }\end{array} \\
\end{array}$ \\
\hline \multicolumn{5}{|l|}{ Investment banking pressure (bank-company relationships) } \\
\hline bank's share of company's equity deals prior 5 years & $\begin{array}{l}0.120^{* * *} \\
0.013\end{array}$ & $\begin{array}{l}0.114^{* * *} \\
0.013\end{array}$ & $\begin{array}{l}1.478^{* * *} \\
0.007\end{array}$ & $\begin{array}{l}0.183^{* * *} \\
0.010\end{array}$ \\
\hline bank's share of company's debt deals prior 5 years & $\begin{array}{l}0.114^{* * *} \\
0.015\end{array}$ & $\begin{array}{l}0.152^{* * *} \\
0.015\end{array}$ & $\begin{array}{l}0.361^{* * *} \\
0.011\end{array}$ & $\begin{array}{l}0.157^{* * *} \\
0.009\end{array}$ \\
\hline \multicolumn{5}{|l|}{ Brokerage pressure (size of brokerage) } \\
\hline $\log$ no. of registered representatives & $\begin{array}{l}0.010^{* * *} \\
0.003\end{array}$ & $\begin{array}{l}0.023^{* * *} \\
0.002\end{array}$ & $\begin{array}{l}0.047^{* * *} \\
0.001\end{array}$ & $\begin{array}{l}0.030^{* * *} \\
0.001\end{array}$ \\
\hline \multicolumn{5}{|l|}{ Bank characteristics } \\
\hline bank's loyalty index & $\begin{array}{l}-0.119^{* * *} \\
0.023\end{array}$ & $\begin{array}{l}-0.193^{* * *} \\
0.019\end{array}$ & $\begin{array}{l}0.424^{* * *} \\
0.008\end{array}$ & $\begin{array}{l}-0.167^{* * *} \\
0.011\end{array}$ \\
\hline bank's equity market share prior calendar year & $\begin{array}{c}-0.401^{* * *} \\
0.098\end{array}$ & $\begin{array}{l}0.054 \\
0.058\end{array}$ & $\begin{array}{c}-0.176^{* * *} \\
0.044\end{array}$ & $\begin{array}{l}0.141^{* *} \\
0.048\end{array}$ \\
\hline \multicolumn{5}{|l|}{ Institutional ownership } \\
\hline$\%$ institutional ownership & $\begin{array}{c}-0.089^{* * *} \\
0.015\end{array}$ & $\begin{array}{c}-0.120^{* * *} \\
0.020\end{array}$ & $\begin{array}{l}0.200^{* * *} \\
0.006\end{array}$ & $\begin{array}{c}-0.070^{* * *} \\
0.008\end{array}$ \\
\hline \multicolumn{5}{|l|}{ Analyst characteristics } \\
\hline$=1$ if analyst is an Institutional Investor "all-star" & $\begin{array}{l}0.008 \\
0.009\end{array}$ & $\begin{array}{l}-0.021^{* * *} \\
0.006\end{array}$ & & $\begin{array}{l}-0.021^{* * *} \\
0.004\end{array}$ \\
\hline relative forecast accuracy & $\begin{array}{l}0.137^{\text {*** }} \\
0.040\end{array}$ & $\begin{array}{l}0.006 \\
0.061^{*} \\
0.028\end{array}$ & & $\begin{array}{l}0.004 \\
0.004 \\
0.015\end{array}$ \\
\hline log analyst's seniority (in years) & $\begin{array}{r}-0.013 \\
0.008\end{array}$ & $\begin{array}{l}0.015^{* * *} \\
0.005\end{array}$ & & $\begin{array}{l}0.011^{* * *} \\
0.002\end{array}$ \\
\hline$=1$ if analyst initiates coverage & $\begin{array}{l}0.005 \\
0.012\end{array}$ & $\begin{array}{l}0.020 \\
0.013\end{array}$ & & $\begin{array}{l}0.015^{*} \\
0.006\end{array}$ \\
\hline log no. of quarters since analyst initiated coverage (seasoning) & $\begin{array}{l}0.018^{* * *} \\
0.004\end{array}$ & $\begin{array}{l}0.021^{* * *} \\
0.004\end{array}$ & & $\begin{array}{l}0.029^{* * *} \\
0.002\end{array}$ \\
\hline jobmove (analyst changing employer) & -0.033 & $-0.068^{* * *}$ & & $-0.052^{* * *}$ \\
\hline log no. of stocks covered by analyst & $\begin{array}{l}0.019 \\
-0.042^{* * *} \\
0.006\end{array}$ & $\begin{array}{l}0.019 \\
-0.033^{* * *} \\
0.005\end{array}$ & & $\begin{array}{l}0.010 \\
-0.032^{* * *} \\
0.003\end{array}$ \\
\hline
\end{tabular}


Table 3. Endogenous coverage selection. (Continued)

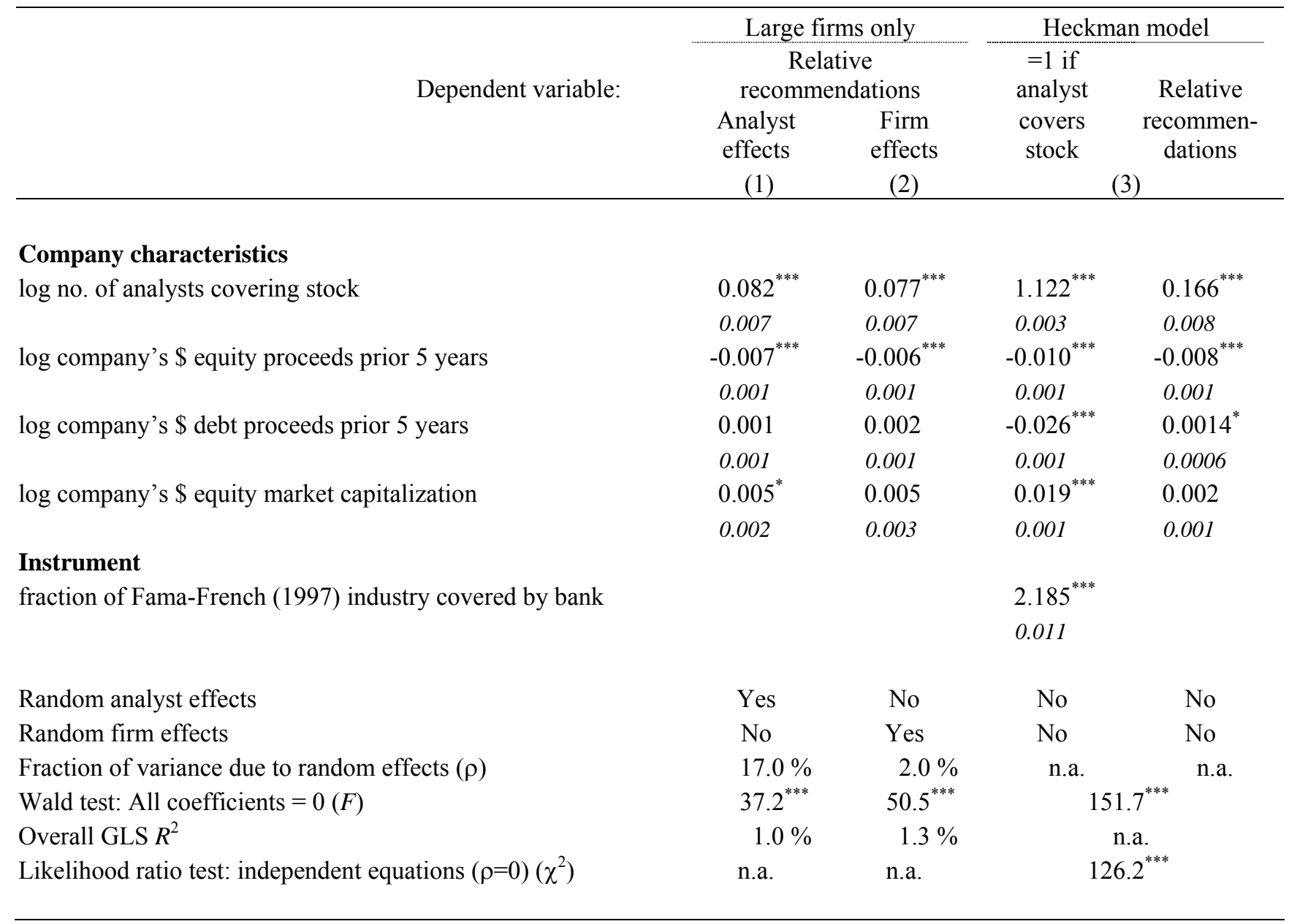


Table 4. The effect of the number of institutional owners.

The dependent variable is relative recommendations, defined as analyst $i$ 's recommendation for company $k$ 's stock relative to consensus (the median recommendation of all other analysts covering firm $k$ ). All models are estimated using randomeffects GLS regressions, including either analyst or firm effects. This table replaces institutional investor holdings from Table 2 with two alternative institutional ownership variables: The log number of institutional investors (see cols. (1) and (2)), and the mean size of institutional investor holdings, computed as (institutional investor holdings) / (number of institutional investors) (see cols. (3) and (4)). To conserve space, intercepts are not shown. Standard errors are shown in italics underneath the coefficient estimates. We use ${ }^{* * *},{ }^{* *}$, and ${ }^{*}$ to denote significance at the $0.1 \%, 1 \%$, and $5 \%$ level (twosided), respectively. The number of observations is 224,280 .

Dependent variable: Relative recommendations (1)

(2)

(3)

(4)

Investment banking pressure (bank-company relationships)

bank's share of company's equity deals prior 5 years

$\begin{array}{llll}0.097^{* * *} & 0.092^{* * *} & 0.097^{* * *} & 0.094^{* * *} \\ 0.006 & 0.006 & 0.006 & 0.006 \\ 0.105^{* * *} & 0.141^{* * *} & 0.105^{* * *} & 0.141^{* * *} \\ 0.009 & 0.009 & 0.009 & 0.009\end{array}$

Brokerage pressure (size of brokerage)

$\log$ no. of registered representatives

$\begin{array}{llll}0.012^{* * *} & 0.024^{* * *} & 0.012^{* * *} & 0.024^{* * *} \\ 0.002 & 0.001 & 0.002 & 0.001\end{array}$

\section{Bank characteristics}

bank's loyalty index

bank's equity market share prior calendar year

\section{Institutional ownership}

$\log$ no. of institutional investors

mean size of institutional investor holdings

$\begin{array}{lc}-0.109^{* * *} & -0.174^{* * *} \\ 0.013 & 0.011 \\ -0.452^{* * *} & 0.007 \\ 0.059 & 0.034 \\ & \\ -0.007 & -0.016^{* * *} \\ 0.004 & 0.005\end{array}$

\section{Analyst characteristics}

$=1$ if analyst is an Institutional Investor "all-star"

relative forecast accuracy

$\log$ analyst's seniority (in years)

$=1$ if analyst initiates coverage

$\log$ no. of quarters since analyst initiated coverage (seasoning)

jobmove (analyst changing employer)

$\log$ no. of stocks covered by analyst

$\begin{array}{llll}0.004 & -0.026^{* * *} & 0.003 & -0.026^{* * *} \\ 0.006 & 0.004 & 0.006 & 0.004 \\ 0.079^{* * *} & 0.005 & 0.078^{* * *} & 0.003 \\ 0.022 & 0.015 & 0.022 & 0.015 \\ 0.002 & 0.018^{* * *} & 0.002 & 0.018^{* * *} \\ 0.005 & 0.003 & 0.005 & 0.003 \\ 0.000 & 0.009 & -0.001 & 0.009 \\ 0.006 & 0.006 & 0.006 & 0.006 \\ 0.018^{* * *} & 0.021^{* * *} & 0.017^{* * *} & 0.020^{* * *} \\ 0.002 & 0.002 & 0.002 & 0.002 \\ -0.041^{* * *} & -0.061^{* * *} & -0.041^{* * *} & -0.061^{* * *} \\ 0.011 & 0.010 & 0.011 & 0.010 \\ -0.042^{* * *} & -0.036^{* * *} & -0.043^{* * *} & -0.037^{* * *} \\ 0.004 & 0.003 & 0.004 & 0.003\end{array}$

$\begin{array}{cc}-0.494^{* * *} & -0.473^{* * *} \\ 0.140 & 0.153\end{array}$

$-0.108^{* * *}-0.173^{* * *}$

$0.013 \quad 0.011$
-0.452

$-0.452^{* * *} \quad 0.005$

$0.059 \quad 0.034$ 
Table 4. The effect of the number of institutional owners. (Continued)

Dependent variable: Relative recommendations

\section{Company characteristics}

$\log$ no. of analysts covering stock

log company’s \$ equity proceeds prior 5 years

log company’s $\$$ debt proceeds prior 5 years

log company’s \$ equity market capitalization

Random analyst effects

Random firm effects

Fraction of variance due to random effects $(\rho)$

Wald test: All coefficients $=0\left(\chi^{2}\right)$

Overall GLS $R^{2}$
(1)

$\begin{array}{llll}0.085^{* * *} & 0.079^{* * *} & 0.084^{* * *} & 0.077^{* * *} \\ 0.004 & 0.004 & 0.004 & 0.004 \\ -0.007^{* * *} & -0.006^{* * *} & -0.007^{* * *} & -0.006^{* * *} \\ 0.001 & 0.001 & 0.001 & 0.001 \\ 0.002^{* *} & 0.002^{*} & 0.002^{* *} & 0.001 \\ 0.0006 & 0.0009 & 0.0006 & 0.001 \\ 0.004 & 0.006 & -0.001 & -0.003 \\ 0.002 & 0.003 & 0.001 & 0.002\end{array}$

Yes

No

$14.8 \%$

$113.5^{* * *}$

$1.2 \%$
(2)

(3)

(4)

No

Yes

Yes

Yes

$3.3 \%$

$14.8 \%$

$114.1^{* * * *}$

$142.6^{* * *}$ 
Table 5. The effect of the composition of institutional ownership.

The dependent variable is relative recommendations, defined as analyst $i$ 's recommendation for company $k$ 's stock relative to consensus (the median recommendation of all other analysts covering firm $k$ ). All models are estimated using randomeffects GLS regressions, including either analyst or firm effects. In this table, we distinguish between the 100 largest institutions judged by their aggregate portfolio valuations as of the last quarter of 1993, and smaller investors. In cols. (1) and (2), we split overall institutional ownership into the holdings of Top 100 investors and the holdings of smaller investors. In cols. (3) and (4) we include the mean size of institutional holdings for these two groups (computed as aggregate ownership / number of investors). To conserve space, intercepts are not shown. Standard errors are shown in italics underneath the coefficient estimates. We use ${ }^{* * *},{ }^{* *}$, and ${ }^{*}$ to denote significance at the $0.1 \%, 1 \%$, and $5 \%$ level (twosided), respectively. The number of observations is 224,352 in columns (1) and (2) and 223,721 in columns (3) and (4).

\section{Dependent variable: Relative recommendations}

\section{Investment banking pressure (bank-company relationships)}

bank's share of company's equity deals prior 5 years

bank's share of company's debt deals prior 5 years

\section{Brokerage pressure (size of brokerage)}

$\log$ no. of registered representatives

\section{Bank characteristics}

bank's loyalty index

bank's equity market share prior calendar year

\section{Institutional ownership}

$\%$ institutional ownership: Top 100 investors

$\%$ institutional ownership: Other investors

mean size of institutional holdings: Top 100 investors

mean size of institutional holdings: Other investors

\section{Analyst characteristics}

$=1$ if analyst is an Institutional Investor "all-star"

relative forecast accuracy

$\log$ analyst's seniority (in years)

$=1$ if analyst initiates coverage

log no. of quarters since analyst initiated coverage (seasoning)

jobmove (analyst changing employer)

$\log$ no. of stocks covered by analyst

\section{(1)}

$\begin{array}{llll}0.094^{* * *} & 0.091^{* * *} & 0.097^{* * *} & 0.093^{* * *} \\ 0.006 & 0.006 & 0.006 & 0.006 \\ 0.105^{* * *} & 0.141^{* * *} & 0.105^{* * *} & 0.141^{* * *} \\ 0.009 & 0.009 & 0.009 & 0.009 \\ & & & \\ 0.012^{* * *} & 0.024^{* * *} & 0.012^{* * *} & 0.024^{* * *} \\ 0.002 & 0.001 & 0.002 & 0.001 \\ & & & \\ -0.109^{* * *} & -0.174^{* * *} & -0.109^{* * *} & -0.174^{* * *} \\ 0.013 & 0.011 & 0.013 & 0.011^{* * *} \\ -0.451^{* * *} & 0.010 & -0.451^{* *} & 0.007 \\ 0.059 & 0.034 & 0.059 & 0.034\end{array}$

$\begin{array}{cc}-0.414^{* *} & -0.477^{* *} \\ 0.138 & 0.154 \\ -0.134 & 0.090 \\ 0.235 & 0.257\end{array}$

$\begin{array}{llll}0.003 & -0.026^{* * *} & 0.004 & -0.026^{* * *} \\ 0.006 & 0.004 & 0.006 & 0.004 \\ 0.078^{* * *} & 0.004 & 0.078^{* * *} & 0.003 \\ 0.022 & 0.015 & 0.022 & 0.015 \\ 0.000 & 0.018^{* * *} & 0.002 & 0.018^{* * *} \\ 0.005 & 0.003 & 0.005 & 0.003 \\ 0.000 & 0.009 & -0.001 & 0.009 \\ 0.006 & 0.006 & 0.006 & 0.006 \\ 0.019^{* * *} & 0.021^{* * *} & 0.017^{* * *} & 0.020^{* * *} \\ 0.002 & 0.002 & 0.002 & 0.002 \\ -0.040^{* * *} & -0.061^{* * *} & -0.041^{* * *} & -0.061^{* * *} \\ 0.011 & 0.010 & 0.011 & 0.010 \\ -0.043^{* * *} & -0.037^{* * *} & -0.043^{* * *} & -0.037^{* * *} \\ 0.004 & 0.003 & 0.004 & 0.003\end{array}$


Table 5. The effect of the composition of institutional ownership. (Continued)

\begin{tabular}{|c|c|c|c|c|}
\hline Dependent variable: Relative recommendations & $(1)$ & (2) & (3) & (4) \\
\hline \multicolumn{5}{|l|}{ Company characteristics } \\
\hline \multirow[t]{2}{*}{$\log$ no. of analysts covering stock } & $0.089^{* * *}$ & $0.080^{* * *}$ & $0.085^{* * *}$ & $0.077^{* * *}$ \\
\hline & 0.004 & 0.004 & 0.004 & 0.004 \\
\hline \multirow[t]{2}{*}{ log company’s $\$$ equity proceeds prior 5 years } & $-0.007^{* * *}$ & $-0.006^{* * *}$ & $-0.007^{* * *}$ & $-0.006^{* * *}$ \\
\hline & 0.001 & 0.001 & 0.001 & 0.001 \\
\hline \multirow[t]{2}{*}{$\log$ company's $\$$ debt proceeds prior 5 years } & $0.0019^{* *}$ & 0.0016 & $0.0019^{* *}$ & 0.0015 \\
\hline & 0.0006 & 0.0009 & 0.0006 & 0.0009 \\
\hline \multirow{2}{*}{ log company’s \$ equity market capitalization } & $0.003^{*}$ & 0.002 & -0.001 & -0.003 \\
\hline & 0.001 & 0.002 & 0.001 & 0.002 \\
\hline Random analyst effects & Yes & No & Yes & No \\
\hline Random firm effects & No & Yes & No & Yes \\
\hline Fraction of variance due to random effects $(\rho)$ & $14.7 \%$ & $3.3 \%$ & $14.8 \%$ & $3.3 \%$ \\
\hline Wald test: All coefficients $=0\left(\chi^{2}\right)$ & $118.8^{* * *}$ & $146.3^{* * *}$ & $113.8^{* * *}$ & $143.1^{* * *}$ \\
\hline Overall GLS $R^{2}$ & $1.2 \%$ & $1.4 \%$ & $1.2 \%$ & $1.4 \%$ \\
\hline
\end{tabular}


Table 6. Determinants of analyst forecast accuracy.

The dependent variable is analyst forecast accuracy relative to consensus, defined as the absolute error of analyst $i$ 's fiscal year-end forecast for company $k$ in quarter $t$ relative to company $k$ 's subsequently realized earnings, scaled by the standard deviation of forecast errors: abs(realized earnings - forecast earnings)/st.dev. We then normalize this measure by subtracting the scaled absolute error of the contemporaneous consensus forecast (taken to be the median forecast) to ensure comparability across companies and across forecast horizons. We estimate two random-effects GLS models, including either analyst or firm random effects, respectively. To conserve space, intercepts effects are not shown. Standard errors are shown in italics underneath the coefficient estimates. We use ${ }^{* * *},{ }^{* *}$, and ${ }^{*}$ to denote significance at the $0.1 \%, 1 \%$, and $5 \%$ level (two-sided), respectively. The number of observations is 231,875 . This is somewhat higher than in the recommendations models shown in Tables 2 through 5, reflecting the tendency of analysts to make more frequent earnings forecasts than recommendations.

\begin{tabular}{ccc}
\hline & Random & Random \\
Dependent variable: Analyst forecast accuracy & analyst firm & effects \\
effects & $(1)$ & $(2)$
\end{tabular}

\section{Investment banking pressure (bank-company relationships)}

bank's share of company's equity deals prior 5 years

$\begin{array}{lc}-0.033^{\text {*** }} & -0.035^{\text {*** }} \\ 0.007 & 0.006 \\ 0.005 & -0.005 \\ 0.010 & 0.010 \\ & \\ -0.008^{* * *} & -0.009^{* * *} \\ 0.001 & 0.001\end{array}$

\section{Bank characteristics}

bank's loyalty index

$\begin{array}{cc}-0.014 & -0.013 \\ 0.013 & 0.012 \\ -0.084 & -0.091^{*} \\ 0.045 & 0.038\end{array}$

\section{Institutional ownership}

$\%$ institutional ownership

$\begin{array}{cc}-0.017^{*} & -0.020^{*} \\ 0.009 & 0.008\end{array}$

\section{Analyst characteristics}

$=1$ if analyst is an Institutional Investor "all-star"

$0.000 \quad-0.006$

relative forecast accuracy

0.005

$-0.744^{* * *}$

0.004

$\log$ analyst's seniority (in years)

0.019

$0.011^{* * *}$

$-0.800^{* * *}$

$=1$ if analyst initiates coverage

0.003

0.018

if analyst initiates coverage

0.005

$0.010^{* * *}$

$\log$ no. of quarters since analyst initiated coverage (seasoning)

0.007

0.003

log no. of quarters since analyst initiated coverage (seasoning)

jobmove (analyst changing employer)

0.009

0.007

$\log$ no. of stocks covered by analyst

0.001

0.002

$-0.018$

0.013

0.001

0.002

$-0.025^{*}$

$-0.008^{*}$

0.012

0.004

0.002

0.003 
Table 6. Determinants of analyst forecast accuracy. (Continued)

\begin{tabular}{lcc}
\hline \multicolumn{1}{c}{ Dependent variable: Analyst forecast accuracy } & $\begin{array}{c}\text { Random } \\
\text { analyst } \\
\text { effects } \\
(1)\end{array}$ & $\begin{array}{c}\text { Random } \\
\text { firm } \\
\text { effects } \\
(2)\end{array}$ \\
\hline Company characteristics & & \\
log no. of analysts covering stock & $0.019^{* * *}$ & $0.017^{* * *}$ \\
log company's \$ equity proceeds prior 5 years & 0.004 & $0.004^{* * *}$ \\
& $0.003^{* * *}$ & $0.003^{*^{* * *}}$ \\
log company's \$ debt proceeds prior 5 years & 0.001 & 0.001 \\
& -0.001 & 0.000 \\
log company's \$ equity market capitalization & 0.001 & 0.001 \\
& $-0.005^{* * *}$ & $-0.004^{* *}$ \\
Random analyst effects & 0.001 & 0.001 \\
Random firm effects & & \\
Fraction of variance due to random effects $(\rho)$ & Yes & No \\
Wald test: All coefficients $=0(F)$ & No & Yes \\
Overall GLS $R^{2}$ & $0.5 \%$ & $0 \%$ \\
& $96.4^{* * *}$ & $139.7^{* * *}$ \\
\hline
\end{tabular}




\section{Table 7. Timeliness of reactions to bad news.}

The sample consists of event-analyst pairs, where the event is defined as a one-day split-adjusted share price drop that exceeds 4 or 5 times the company's prior-year standard deviation of daily returns. These are unusually large price drops. We require consecutive events for the same firm to be at least 3 months apart. For each such event, we find each instance where an analyst (employed at one of our sample banks) covered the company's stock in the 365 days prior to the event (so there are multiple event-analyst pairs for each event). We then compute the time it takes the analyst to react to the price drop by issuing a new report, and regress it on the magnitude of the event-day price drop and the variables introduced in Table 2. We restrict the estimation sample to reaction times of 365 days or less, to focus on recommendation revisions that are likely related to the event. Similar (albeit noisier) results obtain with longer windows, and if we use accelerated-time-tofailure (duration) models. All models are estimated using least-squares and include analyst firm fixed effects. To conserve space, intercepts and fixed effects are not shown. Standard errors are shown in italics underneath the coefficient estimates. We use ${ }^{* * *}, * *$, and ${ }^{*}$ to denote significance at the $0.1 \%, 1 \%$, and $5 \%$ level (two-sided), respectively.

\begin{tabular}{|c|c|c|c|c|}
\hline \multirow[b]{2}{*}{ Dependent variable: $\ln$ time to recommendation revisions } & \multicolumn{2}{|c|}{$4 \mathrm{X}$ price drop } & \multicolumn{2}{|c|}{$5 \mathrm{X}$ price drop } \\
\hline & $(1)$ & (2) & (3) & $(4)$ \\
\hline \multirow[t]{2}{*}{ Magnitude of price drop (one-day return) } & $3.469^{* * *}$ & $3.145^{* * *}$ & $3.021^{* * *}$ & $2.669^{* * *}$ \\
\hline & 0.214 & 0.203 & 0.284 & 0.267 \\
\hline \multicolumn{5}{|l|}{ Analyst characteristics } \\
\hline \multirow[t]{2}{*}{$=1$ if analyst is an Institutional Investor "all-star" } & $-0.136^{*}$ & $-0.143^{*}$ & -0.076 & -0.086 \\
\hline & 0.061 & 0.061 & 0.089 & 0.089 \\
\hline \multirow[t]{2}{*}{ relative forecast accuracy } & -0.435 & -0.427 & $-0.990^{*}$ & $-1.001^{*}$ \\
\hline & 0.308 & 0.309 & 0.459 & 0.460 \\
\hline \multirow[t]{2}{*}{ log analyst's seniority (in years) } & $0.747^{* * *}$ & $0.721^{* * *}$ & $0.717^{* * *}$ & $0.682^{* * *}$ \\
\hline & 0.073 & 0.073 & 0.109 & 0.108 \\
\hline \multirow[t]{2}{*}{ log no. of quarters since analyst initiated coverage (seasoning) } & $0.300^{* * *}$ & $0.266^{* * *}$ & $0.326^{* * *}$ & $0.284^{* * *}$ \\
\hline & 0.023 & 0.022 & 0.033 & 0.032 \\
\hline \multirow[t]{2}{*}{ jobmove (analyst changing employer) } & 0.054 & 0.048 & 0.108 & 0.098 \\
\hline & 0.080 & 0.080 & 0.122 & 0.123 \\
\hline \multirow[t]{2}{*}{$\log$ no. of stocks covered by analyst } & $-0.223^{* * *}$ & $-0.216^{* * *}$ & $-0.369^{* * *}$ & $-0.361^{* * *}$ \\
\hline & 0.048 & 0.048 & 0.071 & 0.071 \\
\hline \multicolumn{5}{|l|}{ Company characteristics } \\
\hline \multirow[t]{2}{*}{$\log$ no. of analysts covering stock } & -0.070 & & -0.064 & \\
\hline & 0.040 & & 0.059 & \\
\hline \multirow[t]{2}{*}{ log company's $\$$ equity proceeds prior 5 years } & 0.010 & & 0.017 & \\
\hline & 0.007 & & 0.010 & \\
\hline \multirow[t]{2}{*}{ log company's $\$$ debt proceeds prior 5 years } & -0.007 & & -0.018 & \\
\hline & 0.007 & & 0.010 & \\
\hline \multirow[t]{2}{*}{ log company's $\$$ equity market capitalization } & $-0.043^{* *}$ & & -0.037 & \\
\hline & 0.014 & & 0.021 & \\
\hline \multicolumn{5}{|l|}{ Investment banking pressure (bank-company relationships) } \\
\hline \multirow[t]{2}{*}{ bank's share of company's equity deals prior 5 years } & 0.033 & $0.119^{*}$ & -0.007 & 0.096 \\
\hline & 0.060 & 0.057 & 0.086 & 0.083 \\
\hline \multirow[t]{2}{*}{ bank's share of company's debt deals prior 5 years } & -0.050 & -0.080 & -0.172 & -0.240 \\
\hline & 0.099 & 0.097 & 0.148 & 0.146 \\
\hline
\end{tabular}


Table 7. Timeliness of reactions to bad news. (Continued)

\begin{tabular}{|c|c|c|c|c|}
\hline \multirow[b]{2}{*}{ Dependent variable: $\ln$ time to recommendation revisions } & \multicolumn{2}{|c|}{$4 \mathrm{X}$ price drop } & \multicolumn{2}{|c|}{$5 \mathrm{X}$ price drop } \\
\hline & $(1)$ & (2) & $(3)$ & $(4)$ \\
\hline \multicolumn{5}{|l|}{ Bank characteristics } \\
\hline \multirow[t]{2}{*}{ bank's loyalty index } & $-0.266^{*}$ & $-0.270^{*}$ & $-0.560^{* *}$ & $-0.561^{* *}$ \\
\hline & 0.132 & 0.132 & 0.197 & 0.197 \\
\hline \multirow[t]{2}{*}{ bank's equity market share prior calendar year } & -0.901 & -0.894 & -0.225 & -0.233 \\
\hline & 0.649 & 0.650 & 0.927 & 0.928 \\
\hline \multicolumn{5}{|l|}{ Institutional ownership } \\
\hline \multirow[t]{2}{*}{$\%$ institutional ownership } & $-0.210^{*}$ & $-0.325^{* * *}$ & $-0.372^{* *}$ & $-0.476^{* * *}$ \\
\hline & 0.086 & 0.083 & 0.126 & 0.122 \\
\hline Analyst fixed effects & Yes & Yes & Yes & Yes \\
\hline Wald test: All coefficients $=0(F)$ & $41.5^{* * *}$ & $71.6^{* * *}$ & $21.4^{* * *}$ & $21.4^{* * *}$ \\
\hline Adjusted $R^{2}$ & $11.4 \%$ & $11.0 \%$ & $10.8 \%$ & $10.4 \%$ \\
\hline Number of observations & 9,956 & 9,956 & 5,842 & 5,842 \\
\hline
\end{tabular}

